Article

\title{
Development of Novel Analogs of the Monocarboxylate Transporter Ligand FACH and Biological Validation of One Potential Radiotracer for Positron Emission Tomography (PET) Imaging
}

\author{
Masoud Sadeghzadeh ${ }^{1, *}\left(\mathbb{D}\right.$, Barbara Wenzel $^{1}{ }^{1}$, Daniel Gündel ${ }^{1}\left(\mathbb{D}\right.$, Winnie Deuther-Conrad ${ }^{1}{ }^{1}$, \\ Magali Toussaint $\left.{ }^{1}{ }^{(}\right)$, Rareş-Petru Moldovan ${ }^{1}{ }^{\circledR}$, Steffen Fischer ${ }^{1}$, Friedrich-Alexander Ludwig ${ }^{1}$, \\ Rodrigo Teodoro ${ }^{1}{ }^{1}$, Shirisha Jonnalagadda ${ }^{2}$, Sravan K. Jonnalagadda ${ }^{2}$, Gerrit Schüürmann ${ }^{3,4}$, \\ Venkatram R. Mereddy ${ }^{2}$, Lester R. Drewes ${ }^{5}$ iD and Peter Brust $^{1}$ (D) \\ 1 Department of Neuroradiopharmaceuticals, Institute of Radiopharmaceutical Cancer Research, \\ Helmholtz-Zentrum Dresden-Rossendorf, Permoserstraße 15, 04318 Leipzig, Germany; \\ b.wenzel@hzdr.de (B.W.); d.guendel@hzdr.de (D.G.); w.deuther-conrad@hzdr.de (W.D.-C.); \\ m.toussaint@hzdr.de (M.T.); r.moldovan@hzdr.de (R.-P.M.); s.fischer@hzdr.de (S.F.); \\ f.ludwig@hzdr.de (F.-A.L.); r.teodoro@hzdr.de (R.T.); p.brust@hzdr.de (P.B.) \\ 2 Department of Chemistry and Biochemistry, Department of Pharmacy Practice \& Pharmaceutical Sciences, \\ University of Minnesota, Duluth, MN 55812, USA; sgurrapu@d.umn.edu (S.J.); skjonnal@d.umn.edu (S.K.J.); \\ vmereddy@d.umn.edu (V.R.M.) \\ 3 UFZ Department of Ecological Chemistry, Helmholtz Centre for Environmental Research, Permoserstraße 15, \\ 04318 Leipzig, Germany; gerrit.schuurmann@ufz.de \\ 4 Institute of Organic Chemistry, Technical University Bergakademie Freiberg, Leipziger Straße 29, \\ 09599 Freiberg, Germany \\ 5 Department of Biomedical Sciences, University of Minnesota Medical School Duluth, 251 SMed, 1035 \\ University Drive, Duluth, MN 55812, USA; ldrewes@d.umn.edu \\ * Correspondence: m.sadeghzadeh@hzdr.de; Tel.: +49-341-2341794630; Fax: +49-341-2341794699
}

Academic Editors: Anne Roivainen and Xiang-Guo Li

Received: 26 March 2020; Accepted: 11 May 2020; Published: 14 May 2020

check for updates

\begin{abstract}
Monocarboxylate transporters 1-4 (MCT1-4) are involved in several metabolism-related diseases, especially cancer, providing the chance to be considered as relevant targets for diagnosis and therapy. $\left[{ }^{18} \mathrm{~F}\right] \mathrm{FACH}$ was recently developed and showed very promising preclinical results as a potential positron emission tomography (PET) radiotracer for imaging of MCTs. Given that $\left[{ }^{18} \mathrm{~F}\right] \mathrm{FACH}$ did not show high blood-brain barrier permeability, the current work is aimed to investigate whether more lipophilic analogs of FACH could improve brain uptake for imaging of gliomas, while retaining binding to MCTs. The 2-fluoropyridinyl-substituted analogs 1 and $\mathbf{2}$ were synthesized and their MCT1 inhibition was estimated by $\left[{ }^{14} \mathrm{C}\right]$ lactate uptake assay on rat brain endothelial-4 (RBE4) cells. While compounds 1 and 2 showed lower MCT1 inhibitory potencies than FACH $\left(\mathrm{IC}_{50}=11 \mathrm{nM}\right)$ by factors of 11 and 25 , respectively, $\mathbf{1}\left(\mathrm{IC}_{50}=118 \mathrm{nM}\right)$ could still be a suitable PET candidate. Therefore, $\mathbf{1}$ was selected for radiosynthesis of $\left[{ }^{18} \mathrm{~F}\right] \mathbf{1}$ and subsequent biological evaluation for imaging of the MCT expression in mouse brain. Regarding lipophilicity, the experimental $\log \mathrm{D}_{7.4}$ result for $\left[{ }^{18} \mathrm{~F}\right] \mathbf{1}$ agrees pretty well with its predicted value. In vivo and in vitro studies revealed high uptake of the new radiotracer in kidney and other peripheral MCT-expressing organs together with significant reduction by using specific MCT1 inhibitor $\alpha$-cyano-4-hydroxycinnamic acid. Despite a higher lipophilicity of $\left[{ }^{18} \mathrm{~F}\right] \mathbf{1}$ compared to $\left[{ }^{18} \mathrm{~F}\right] \mathrm{FACH}$, the in vivo brain uptake of $\left[{ }^{18} \mathrm{~F}\right] \mathbf{1}$ was in a similar range, which is reflected by calculated BBB permeabilities as well through similar transport rates by MCTs on RBE4 cells. Further investigation is needed to clarify the MCT-mediated transport mechanism of these radiotracers in brain.
\end{abstract}


Keywords: monocarboxylate transporters (MCTs); FACH; ${ }^{18}$ F-labeled analog of FACH; $\alpha$-CCA; blood-brain barrier (BBB); positron emission tomography (PET) imaging

\section{Introduction}

Monocarboxylate transporters (MCTs), comprising 14 isoforms, are dedicated to the solute carrier 16 (SLC16) gene family [1,2]. Of all the MCT isoforms, MCT1-4 are well characterized and known as membrane-bound carriers that bidirectionally transport short-chain monocarboxylic acids, most notably L-lactate, pyruvate, and ketone bodies along with protons across the plasma membrane of mammalian cells [2]. The tissue distribution of the MCT isoforms is quite variable. Although MCT1 is ubiquitously distributed in the muscles, it is additionally expressed along with MCT4 in the brain and other peripheral organs like small intestine, liver, heart, kidney, and blood cells [1,3]. Aberrant expression such as, upregulation of MCT1 and MCT4 has been reported in a large number of tumors (e.g., neuroblastomas, high-grade gliomas, carcinomas of renal cells, breast epithelium, colorectal and squamous tissues, and cervical and lung cancers) where expression is correlated to poor outcomes. In these tissues, the MCTs serve to facilitate the shuttling of lactate between cells with different metabolic requirements [4-6]. Due to the metabolic reprogramming, considered as a hallmark of cancer, tumor cells indeed switch from glucose to lactate as a crucial energy supply, hence, their metabolism heavily relies on glycolysis and consequently the lactate efflux through MCT1 and MCT4 in order to prevent their own acidosis and to regenerate $\mathrm{NAD}^{+}$[7]. Accordingly, both transporters are attractive therapeutic and even diagnostic targets for the treatment and detection of human cancers $[4,7,8]$.

Positron emission tomography (PET) is known as a powerful tool for non-invasive molecular detection of early metabolic changes in cancer progression [9]. [ $\left.{ }^{18} \mathrm{~F}\right]$ Fluorodeoxyglucose $\left(\left[{ }^{18} \mathrm{~F}\right] \mathrm{FDG}\right)$, a radiolabeled glucose analog, is well known as a standard PET tracer used for diagnosis, staging and treatment monitoring in clinical oncology [10,11]. Considering the lack of specificity and sensitivity of $\left[{ }^{18} \mathrm{~F}\right]$ FDG for several types of tumors [10], there is still an unmet clinical need for cancer detection and therapy. Thus, the complementary concept based on components of the aerobic glycolysis and metabolism by malignant cells is more intriguing and potentially rewarding [2,12-14]. In this regard, $\left[{ }^{18}\right.$ F]DASA-23, recently developed as a potent radiotracer for imaging tumor glycolysis by targeting pyruvate kinase M2, is currently in phase I clinical trials (ClinicalTrials.gov, NCT03539731) [15]. Because the metabolic reprogramming in cancer cells may also result in the overexpression of MCT1/MCT4 in many cancers [4,7], MCT-targeting PET studies provide an opportunity to achieve more accurate and useful understanding of certain aspects of the tumor-specific metabolism $[8,16]$.

During the last decade, only a few ${ }^{11} \mathrm{C}$ - or ${ }^{18} \mathrm{~F}$-labeled substrates of MCTs such as [ $\left.{ }^{11} \mathrm{C}\right]$ lactate, $\left[{ }^{11} \mathrm{C}\right.$ ]pyruvate as well as their ${ }^{18} \mathrm{~F}$-labeled analogs were investigated for imaging of MCTs by PET [17-20]. To the best of our knowledge, only limited examples of the MCTs inhibitors were investigated as PET radiotracers for in vivo applications [21]. Although one of the best characterized inhibitors, $\alpha$-cyano-4-hydroxycinnamic acid ( $\alpha$-CCA), possesses a 10-fold selectivity for MCT1 compared to other subtypes (Figure 1) [22], it also shows significant inhibitory potency towards the mitochondrial pyruvate carrier in isolated mitochondria [23]. Accordingly, very potent and more specific MCT1/MCT4 inhibitors have been developed based on a comprehensive structure-activity relationship study on a series of $\alpha$-CCA derivatives [24,25]. Based on this approach, we recently developed and evaluated $\left[{ }^{18} \mathrm{~F}\right] \mathrm{FACH}$ as the first ${ }^{18} \mathrm{~F}-$ labeled inhibitor of MCTs (Figure 1) [26]. Along with a high inhibitory potency towards MCT1 (11.0 $\mathrm{nM})$ and MCT4 (6.5 nM) [26], [ [18F]FACH showed very promising pharmacokinetics in healthy mice, in particular in the kidneys, as organ with a high physiological expression of MCT1 [1,3,27]. 


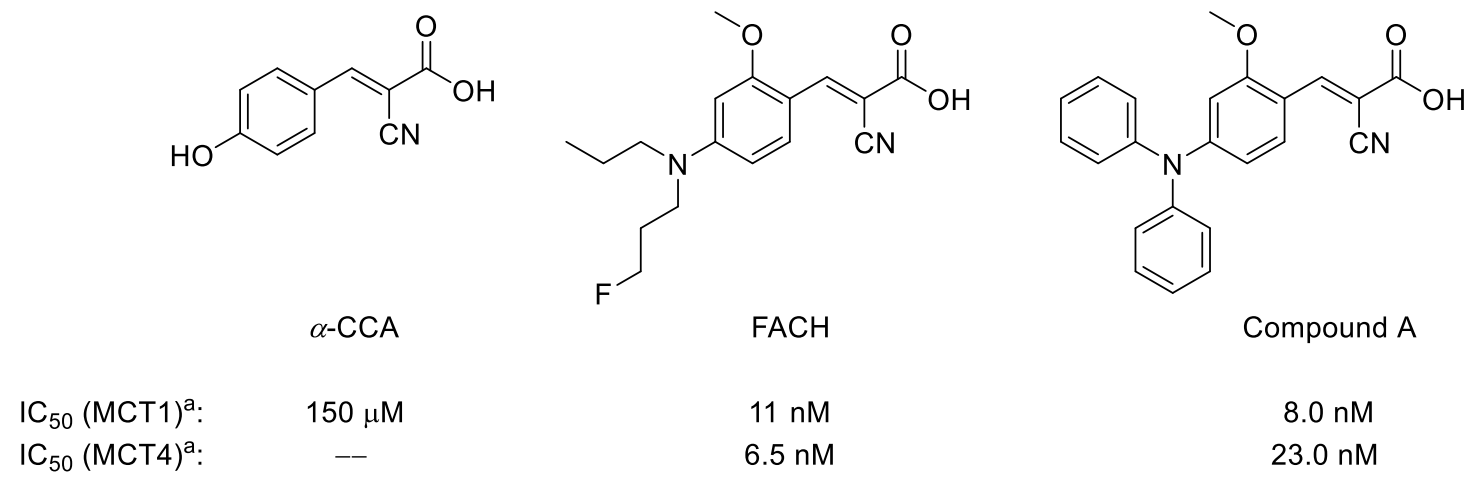

Figure 1. Chemical structures of $\alpha$-CCA and its novel derivatives as potent monocarboxylate transporters 1/4 (MCT1/MCT4) inhibitors; ${ }^{a}$ Inhibition of $\left[{ }^{14} \mathrm{C}\right]$ lactate uptake was determined in RBE4 cells (for MCT1) and in MDA-MB-231 cells (for MCT4) by measuring intracellular radioactivity after $60 \mathrm{~min}$ incubation without and with the respective inhibitor at $37^{\circ} \mathrm{C}$ [25].

Nonetheless, $\left[{ }^{18} \mathrm{~F}\right] \mathrm{FACH}$ showed only moderate brain uptake, which might be related to the rather hydrophilic features $\left(\log \mathrm{D}_{7.4}=0.42\right)$ [28], assuming that $\left[{ }^{18} \mathrm{~F}\right] \mathrm{FACH}$ could only passively enter the brain. This assumption would be in accordance with the fact that for the structural analog $\alpha$-CCA, the site of its MCT inhibition has been demonstrated to be the extracellular surface [29,30]. Moreover, it is well established that MCT1 is also the prominent monocarboxylic acid transporter in the cerebral microvascular endothelium, facilitating the bidirectional transport of lactate through brain endothelial cells and the blood-brain barrier (BBB) [31]. Many brain tumors, such as gliomas and neuroblastomas, produce high amounts of lactic acid and consequently up-regulate MCT1, thus, inducing acidosis in the tumor microenvironment [5]. MCT1 is therefore proposed as a most likely therapeutic target for neuroblastomas and gliomas, and $\alpha$-CCA has been able to suppress tumor growth via inhibition of MCT1 [5,32,33]. Accordingly, the development of MCT1-targeting radiotracers possessing sufficiently high brain permeability would be an important step forward toward brain imaging.

Although $\alpha$-CCA as well as its new analog FACH (Figure 1) contain a Michael acceptor unit, their highly predominating carboxylate form under physiological conditions (ACD-calculated $\mathrm{p} K_{\mathrm{a}}<1 \mathrm{vs}$. pH 7.4; see Table 1 below) masks a respective electrophilic reactivity. This implies that these compounds are most likely not active as protein-attacking electrophiles. Moreover and as mentioned above, $\alpha-C C A$ has been reported to remain extracellular, inhibiting MCT from the outside in a competitive manner and without adverse effects under therapeutic concentrations [29,30].

In this context, it is interesting that for all respective cinnamic acid derivatives, the electron-withdrawing $\alpha$-CN substituent is required for their MCT inhibition potency, which holds also for $\mathrm{FACH}$ [26]. As a possible explanation, we hypothesize that their non-covalent interaction with the MCT protein at the cellular surface may include an electrostatic Arg-carboxylate binding motif as primary anchor. This may facilitate a further complex stabilization through approaching a Cys-thiol by the Michael acceptor $\beta$-carbon that is activated further through the $\alpha$-CN substitution (Figure 2, left). To balance the carboxylate anionic charge, a separate extracellular proton, required for the MCT action as respective symporter, could be attached temporarily at a His-nitrogen (not shown in Figure 2). In case of a successful carboxylate transport such as for the lactate efflux, a respective (additional) His-proton could be liberated to the interstitial compartment. 
<smiles>[R]c1ccc(/C=C(\C#N)C(=O)O)c(OC)c1</smiles>

Protein-surface receptor site<smiles>[R]c1ccc(C(S[Se][Ba])C([M])C(=O)O)c(OC)c1</smiles>

Water-poor/free receptor site

Figure 2. Hypothetical MCT-inhibitor binding at the extracellular surface (left) and at an interior protein site with no aqueous solvation (right). Michael addition may become active for the neutral carboxylic acid form (right), but would be reversible due to the $\alpha$-CN substitution that enhances the retro-Michael reaction significantly (see, e.g., [34,35]).

In case the Arg-carboxylate interaction would result in a charge compensation sufficient to unmask the Michael acceptor reactivity, the Cys-thiol might add to the $\alpha, \beta$-unsaturated unit, possibly following a proton transfer from Arg to the carboxylate (right part of Figure 2). In this case, however, the $\alpha-\mathrm{CN}$ substituent enhances both the Michael and the retro-Michael reactivity, making this covalent reaction reversible through stabilization of the carbanion intermediate [34,35]. In conclusion, we hypothesize that despite the Michael acceptor unit common to all cinnamic acid derivatives, their mode of action is probably non-covalent or under water-poor/free conditions at least only temporarily covalent, with a correspondingly negligible risk to form permanent covalent bonds to nucleophilic protein sites. Results from a respective toxicity study will be reported in due course.

With the goal to improve the brain uptake by passive diffusion, we designed new analogs of FACH by replacing the less lipophilic propyl groups with more lipophilic aryl and heteroaryl moieties (Figure 3). Notably, the structurally modified analogs yet need to retain an acceptable inhibitory potency towards MCT1. On the basis of compound A, which was reported to exhibit high MCT1 inhibition $\left(\mathrm{IC}_{50}=8.0 \mathrm{nM}\right.$, Figure 1) [25], two fluorinated analogs were developed by introducing 2-fluoropyridinyl and phenyl groups (compounds 1 and 2, Figure 3). Herein we describe the organic synthesis of the new compounds and their inhibitory potency for MCT1-mediated lactate transport. Furthermore, radiofluorination of $\mathbf{1}$ was performed and the resulting new radiotracer $\left[{ }^{18} \mathrm{~F}\right] \mathbf{1}$ was investigated in mice to assess the impact of higher lipophilicity on the in vivo features compared to $\left[{ }^{18} \mathrm{~F}\right] \mathrm{FACH}$ for imaging of MCT1 in mouse brain.

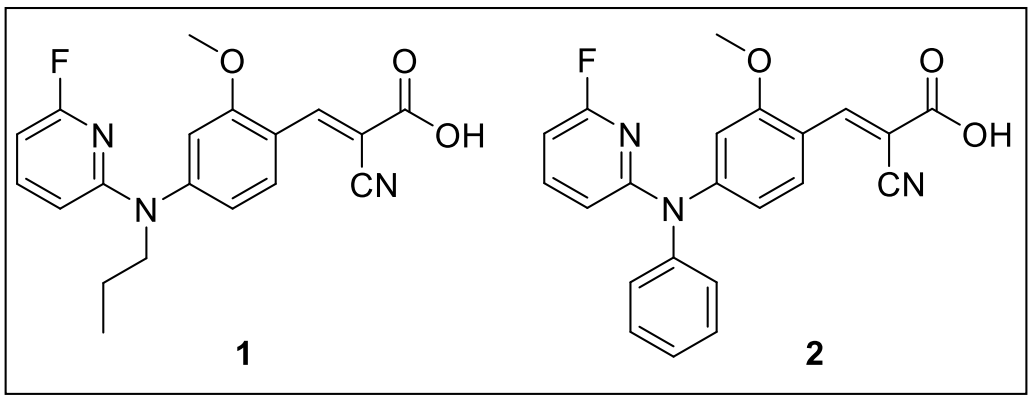

Figure 3. New analogs of FACH investigated in the current study.

\section{Results and Discussion}

\subsection{Organic Chemistry and Monocarboxylate Transporter Inhibition}

For developing the compounds $\mathbf{1}$ and $\mathbf{2}$, the di-arylamine intermediate $\mathbf{5}$ was synthesized via the Buchwald-Hartwig aryl amination according to the previously reported procedures (Scheme 1) [36,37]. 
Alkylation of 6-fluoro- $N$-(3-methoxyphenyl)pyridin-2-amine 5 using 1-iodopropane and sodium hydride afforded 6 in 95\% yield [38]. Compound 7 was obtained via a second Buchwald-Hartwig amination of 5 with phenyl bromide in negligible yield $(<10 \%)$. However, a stepwise addition of the palladium $(\mathrm{Pd})$ catalyst and the phosphine ligand together with a longer reaction time led to the formation of $\mathbf{7}$ in moderate yield (46\%). This might be related to the decreased electron density of the nitrogen atom due to the 2-fluoropyridinyl substituent and/or the steric hindrance effect. Both $\mathbf{6}$ and $\mathbf{7}$ were afterwards subjected to Vilsmeier-Haack formylation [39] to afford 8 and 9 with yields of $57 \%$ and $68 \%$, respectively. Finally, Knoevenagel condensation of aldehydes 8 and 9 with cyanoacetic acid generated $\mathbf{1}$ and $\mathbf{2}$ in nearly quantitative yields (Scheme 1) [26].

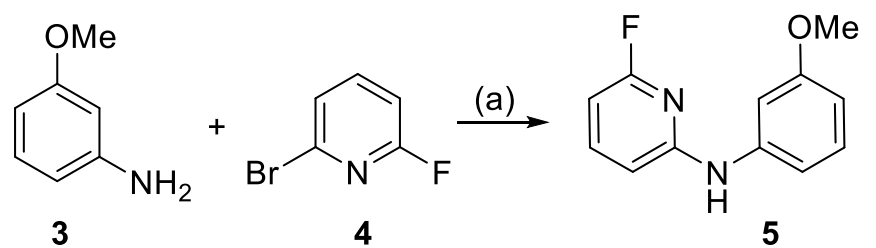

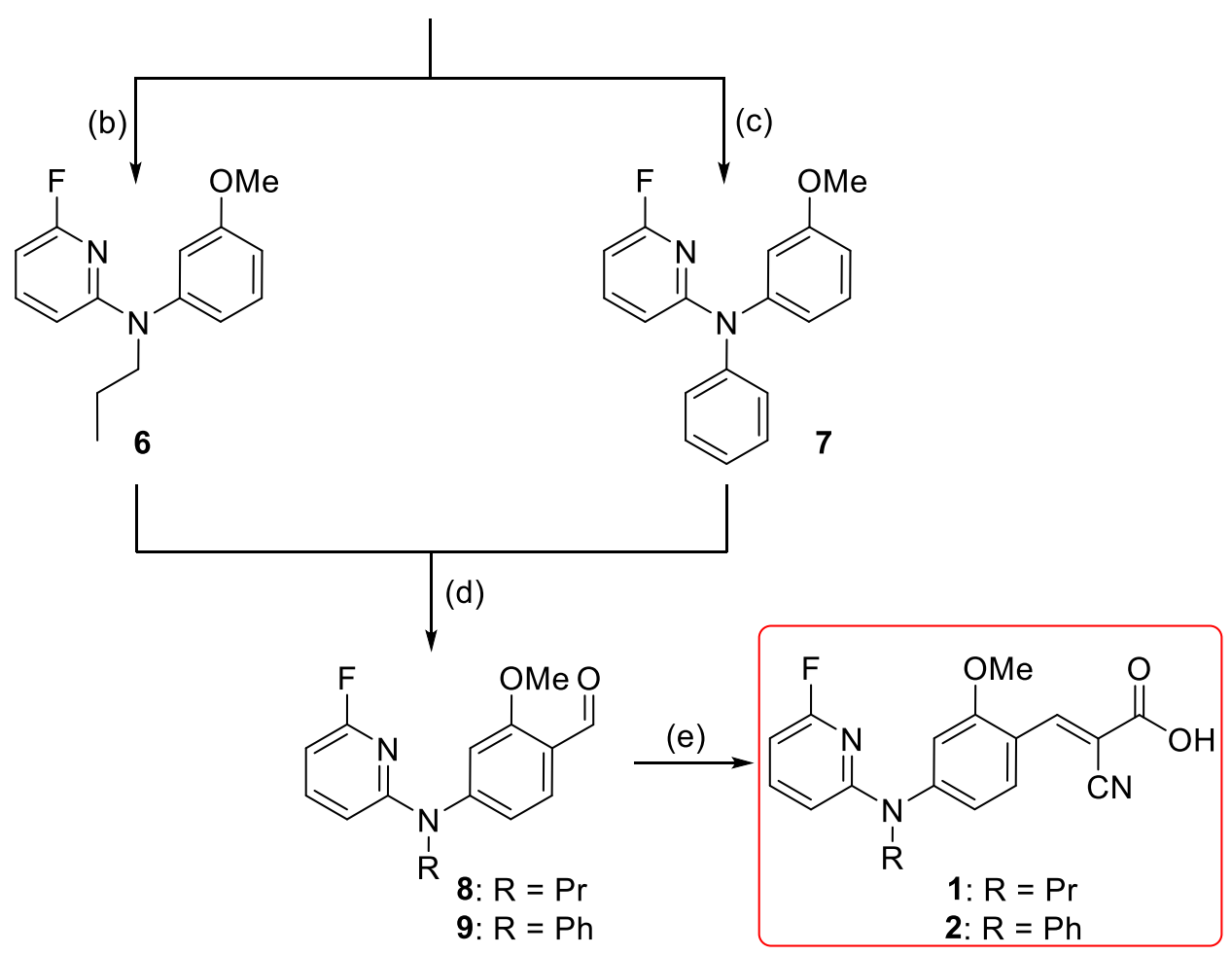

Scheme 1. Synthesis of 1 and 2; reagents and reaction conditions: (a) $\mathrm{Pd}(\mathrm{OAc})_{2}(5 \mathrm{~mol} \%)$, Xantphos (5 $\mathrm{mol} \%$ ), $\mathrm{Cs}_{2} \mathrm{CO}_{3}, 1,4$-dioxane, $\mathrm{Ar}, 105^{\circ} \mathrm{C}, 50 \mathrm{~min}, 96 \%$; (b) 1-iodopropane, $\mathrm{NaH}$ (60\% oil dispersion), DMF, Ar, r.t., 1.5 h, 95\%; (c) $\mathrm{PhBr}, \mathrm{Pd}(\mathrm{OAc})_{2}$ (15 mol \%), Xantphos (15 mol \%), $\mathrm{Cs}_{2} \mathrm{CO}_{3}, 1,4$-dioxane, $\mathrm{Ar}$, $105{ }^{\circ} \mathrm{C}, 24 \mathrm{~h}, 46 \%$; (d) $\mathrm{POCl}_{3}, \mathrm{DMF}, \mathrm{Ar}, 80{ }^{\circ} \mathrm{C}, 2-4 \mathrm{~h}, 57 \%$ (for 8 ) and $68 \%$ (for 9); (e) i. cyanoacetic acid, piperidine, $\mathrm{ACN}$, reflux; ii. $\mathrm{HCl}(6 \mathrm{M})$, r.t. $30 \mathrm{~min}, 95 \%$ (for 1 ) and $98 \%$ (for 2).

Inhibition of MCT1-mediated lactate transport of $\mathbf{1}$ and $\mathbf{2}$ was investigated by $\left[{ }^{14} \mathrm{C}\right]$ lactate uptake assays using immortalized rat brain endothelial-4 cells (RBE4) [40] which express mainly MCT1 [24,25]. Both compounds dose-dependently inhibited the lactate uptake, with $\mathrm{IC}_{50}$ values of $118 \mathrm{nM}$ (1) and $274 \mathrm{nM}$ (2). Accordingly, replacing the 1-fluoropropyl group of FACH by a 2-fluoropyridinyl group in 1 resulted in a 10-fold decrease of the inhibitory potency. When comparing 2 with compound A, the substitution of the phenyl ring by a 2-fluoropyridinyl ring in 2 (Figure 1) caused an even stronger reduction of the inhibitory potency [25]. We therefore decided to proceed with $\mathbf{1}$ for radiofluorination and biological evaluation. 
In order to develop the new MCT1-targeting radiotracer $\left[{ }^{18} \mathrm{~F}\right] \mathbf{1}$, a precursor including a suitable leaving group was required for the nucleophilic aromatic substitution $\left(\mathrm{S}_{\mathrm{N}} \mathrm{Ar}\right)$ with $\left[{ }^{18} \mathrm{~F}\right]$ fluoride. A nitro precursor (15) with an unprotected carboxylic acid function (Scheme 2) was synthesized considering the good results obtained for the aliphatic nucleophilic substitution with unprotected precursor in the one-step radiosynthesis of $\left[{ }^{18} \mathrm{~F}\right] \mathrm{FACH}$ [28]. Initial Buchwald-Hartwig aryl amination between 2-amino-6-nitropyridine and 3-bromoanisole provided the $N$-substituted anisidine 12 in $80 \%$ yield (Scheme 2) [36]. Alkylation of 12 under basic condition provided 13 with a yield of 93\% [38]. Vilsmeier-Haack formylation of 13 gave aldehyde $\mathbf{1 4}$ in 92\% yield [39]. It was followed by Knoevenagel condensation with cyanoacetic acid to provide 15 in $67 \%$ overall yield [26]. The chemical purity of the precursor 15 was $>98 \%$, according to NMR and HPLC analyses.<smiles>CCCN(c1cccc(OC)c1)c1cccc(N(CC)c2cccc(Nc3cccc([N+](=O)[O-])n3)c2)c1</smiles>

(c)<smiles>CCCN(c1ccc(C=O)c(OC)c1)c1cccc([N+](=O)[O-])n1</smiles>

(d)<smiles>CCCN(c1ccc(/C=C(\C#N)C(=O)O)c(OC)c1)c1cccc([N+](=O)[O-])n1</smiles>

Scheme 2. Synthesis of the nitro precursor (15): Reagents and reaction conditions: (a) $\mathrm{Pd}(\mathrm{OAc})_{2}(5$ $\mathrm{mol} \%$ ), Xantphos (5 mol \%), $\mathrm{Cs}_{2} \mathrm{CO}_{3}, 1$,4-dioxane, $\mathrm{Ar}, 105^{\circ} \mathrm{C}, 2 \mathrm{~h}, 80 \%$; (b) 1-iodopropane, $\mathrm{NaH}(60 \%$ oil dispersion), DMF, Ar, r.t., $1.5 \mathrm{~h}, 93 \%$; (c) $\mathrm{POCl}_{3}, \mathrm{DMF}, \mathrm{Ar}, 80{ }^{\circ} \mathrm{C}, 1.5 \mathrm{~h}, 92 \%$; (d) i. cyanoacetic acid, piperidine, ACN, reflux, 5 h; ii. $\mathrm{HCl}(6 \mathrm{M})$, r.t. $30 \mathrm{~min}$, above $98 \%$.

\subsection{Radiosynthesis, Stability, and Determination of $\log D_{7.4}$}

As shown in Scheme 3, $\left[{ }^{18} \mathrm{~F}\right] \mathbf{1}$ was synthesized on the basis of an $\mathrm{S}_{\mathrm{N}} \mathrm{Ar}$ reaction via substitution of the $\mathrm{NO}_{2}$ leaving group of 15 by $\left[{ }^{18} \mathrm{~F}\right]$ fluoride in the presence of Kryptofix ${ }^{\circledR}\left(\mathrm{K}_{2.2 .2}\right)$ and $\mathrm{K}_{2} \mathrm{CO}_{3}$. In dimethylsulfoxide (DMSO), the $\mathrm{S}_{\mathrm{N}} \mathrm{Ar}$ reaction proceeded smoothly and resulted in high radiochemical yields of $73 \pm 12 \%\left(\mathrm{n}=4\right.$, non-isolated, radio-HPLC) for $\left[{ }^{18} \mathrm{~F}\right] \mathbf{1}$ after $15 \mathrm{~min}$ conventional heating at $130{ }^{\circ} \mathrm{C}$. Besides unreacted $\left[{ }^{18} \mathrm{~F}\right] \mathrm{F}^{-}$, radioactive by-products accounted for less than $5 \% .\left[{ }^{18} \mathrm{~F}\right] 1$ was isolated by semi-preparative HPLC (Supplementary Data, Figure S1A), trapped on a pre-conditioned Sep-Pak C18 light cartridge, eluted with ethanol, and formulated in isotonic saline containing $10 \%$ of EtOH (v/v) for better solubility. Analytical radio- and UV-HPLC analyses of the final product co-eluted with the reference 1, confirmed the identity of the radiotracer (Supplementary Data, Figure S1B). Finally, $\left[{ }^{18} \mathrm{~F}\right] \mathbf{1}$ was obtained with radiochemical yields of $51 \pm 11 \%(\mathrm{n}=3$, decay-corrected to the end of the bombardment) in a total radiosynthesis time of about $90 \mathrm{~min}$, at a radiochemical purity of $\geq 98 \%$ and with molar activities in the range of $180-200 \mathrm{GBq} / \mu \mathrm{mol}(\mathrm{n}=3$, end of synthesis) using starting activities of $2-3 \mathrm{GBq}$. 


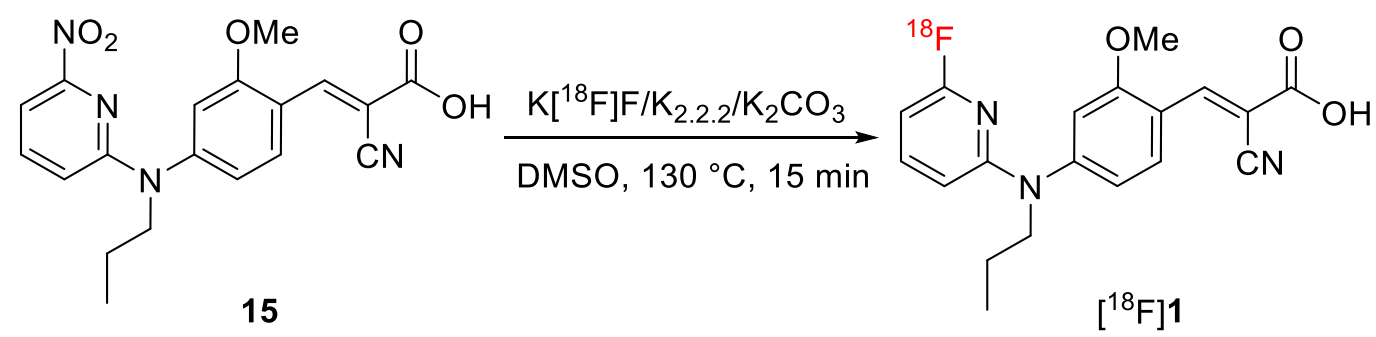

Scheme 3. Radiosynthesis of $\left[{ }^{18} \mathrm{~F}\right] \mathbf{1}$.

The stability of the radiotracer was investigated by incubation of $\left[{ }^{18} \mathrm{~F}\right] 1$ in $n$-octanol, saline, phosphate-buffered saline (PBS) and ethanol. Samples were analyzed by radio-thin-layer chromatography (TLC) and radio-HPLC and no degradation or defluorination was observed in any of the solvents after $60 \mathrm{~min}$ incubation at $40^{\circ} \mathrm{C}$.

A variety of physicochemical parameters affects the brain permeability of different brain-targeting radiotracers [41]. Lipophilicity, often, but not necessarily, correlates with the ability to cross the BBB, and is considered as an important physicochemical property. In Table 1, calculated bioavailability-related parameters are listed for $\alpha$-CCA, FACH and selected structural analogs. Accordingly, the new derivatives 1 and 2 show the desired higher hydrophobicity $\left(\log K_{\mathrm{ow}}=\operatorname{logarithmic} n\right.$-octanol/water partition coefficient [42], $\log \mathrm{D}_{7.4}=\log K_{\mathrm{ow}}$ corrected for ionization at $\mathrm{pH} 7.4$ [43,44]) as compared to FACH. Nevertheless, Table 1 also shows that the predicted brain-blood partition coefficients (log $K_{\mathrm{BB}}$ [43]) of $\mathbf{1}(-0.49)$ and $\mathbf{2}(-1.05)$ are below the one of FACH $(-0.10)$.

Table 1. Calculated physicochemical parameters of our drug candidates and structurally related compounds. ${ }^{1}$

\begin{tabular}{cccccc}
\hline Compound & $\log K_{\mathbf{o w}}$ & $\log \mathbf{D}_{\mathbf{7 . 4}}$ & $f_{\mathbf{u}}$ & $\mathrm{p} K_{\mathbf{a}}$ & $\log K_{\mathbf{B B}}$ \\
\hline FACH & 4.43 & 0.69 & $4.5 \times 10^{-8}$ & 0.05 & -0.10 \\
Compound A & 5.41 & 1.66 & $2.5 \times 10^{-7}$ & 0.80 & -0.57 \\
$\mathbf{1}$ & 4.83 & 1.08 & $7.4 \times 10^{-8}$ & 0.27 & -0.49 \\
$\mathbf{2}$ & 5.07 & 1.32 & $2.1 \times 10^{-7}$ & 0.73 & -1.05 \\
Cinnamic acid & 2.07 & -0.91 & $8.7 \times 10^{-4}$ & 4.34 & -0.14 \\
$\alpha$-CN cinnamic acid & 2.27 & -1.48 & $1.6 \times 10^{-7}$ & 0.60 & -0.54 \\
$\alpha$-CCA & 1.79 & -1.96 & $2.8 \times 10^{-7}$ & 0.85 & -0.45
\end{tabular}

\footnotetext{
1 The decadic logarithms of the $n$-octanol/water partition coefficient $\left(\log K_{\text {ow }}\right)$ have been calculated with EPI Suite [42], and these values have been employed for predicting the $\mathrm{p} K_{\mathrm{a}}-\mathrm{pH}$-corrected $n$-octanol/water distribution coefficients, $\log \mathrm{D}_{7.4}$. For the latter, the ACD approach $\log K_{\mathrm{ow}}$ (ionized) $=\log K_{\mathrm{ow}}$ (unionized) -3.75 (applicable for the relevant range of $\log K_{\text {ow }}$ data) [43,44] with $D_{7.4}=f_{\mathrm{u}} \times K_{\mathrm{ow}}+\left(1-f_{\mathrm{u}}\right) \times K_{\mathrm{ow}}$ (ionized) has been employed (see also [44]). Note that the ACD-calculated $\log K_{\text {ow }}$ data are lower by 0.5-1.5 log units except for a slightly larger value for cinnamic acid, resulting in correspondingly lower calculated $\log \mathrm{D}_{7.4}$ data. Moreover, $f_{\mathrm{u}}$ denotes the compound fraction unionized at $\mathrm{pH} 7.4$ according to the Henderson-Hasselbalch relationship, and $\mathrm{p} K_{\mathrm{a}}$ as well as the brain-blood partition coefficient $\left(K_{\mathrm{BB}}\right)$ have been calculated with the ACD software.
}

Note further that FACH is both more lipophilic and more BBB-permeable than $\alpha$-CCA. Regarding the Michael-acceptor unit mentioned above, comparison of cinnamic acid and its $\alpha$-CN derivative shows that the $\alpha-C N$ substitution decreases the $\mathrm{p} K_{\mathrm{a}}$ value by 3.7 units, most likely because of its combined inductive and mesomeric electron-withdrawing effect. Accordingly, all $\alpha$-CCA derivatives are significantly acidic with $\mathrm{p} K_{\mathrm{a}}$ values below 1 , indicating for all of them that the dissociated carboxylate form is prevalent under physiological conditions. Experimental investigation of the lipophilicity of $\left[{ }^{18} \mathrm{~F}\right] 1$ through employing the shake-flask method using $n$-octanol and PBS (pH 7.4) resulted in a log $\mathrm{D}_{7.4}$ value of $0.820 \pm 0.003(\mathrm{n}=4)$. This value agrees pretty well with its calculated counterpart of 1.08 (Table 1), which holds correspondingly for the FACH $\log \mathrm{D}_{7.4}$ value (0.42 experimental [28] vs. 0.69 calculated) as well as for the respective difference in $\log \mathrm{D}_{7.4}$ values. 


\subsection{In Vitro and In Vivo Biological Validation of $\left[{ }^{18} \mathrm{~F}\right] 1$}

It is well demonstrated that several members of the MCT family are highly expressed in mammalian kidney, where over $95 \%$ of the lactate reabsorption takes place $[1,3,45,46]$. MCT1 mRNA and protein have clearly been detected on both the human kidney derived cell line HK-2 and human kidney cortex. In HK-2 cells it was found exclusively on the basal membrane [45]. Therefore, the specific binding of $\left[{ }^{18} \mathrm{~F}\right] \mathbf{1}$ to MCTs was initially proven by in vitro autoradiography using cryosections of the mouse kidney. As reflected by the autoradiographic images presented in Figure 4, co-incubation of $\sim 1 \mathrm{nM}$ $\left[{ }^{18} \mathrm{~F}\right] 1$ with $10 \mu \mathrm{M} \alpha$-CCA-Na resulted in significantly lower binding of the radiotracer. Therefore, the binding of $\left[{ }^{18} \mathrm{~F}\right] \mathbf{1}$ in mouse kidney in vitro is highly specific.

$\mathbf{A}$

B

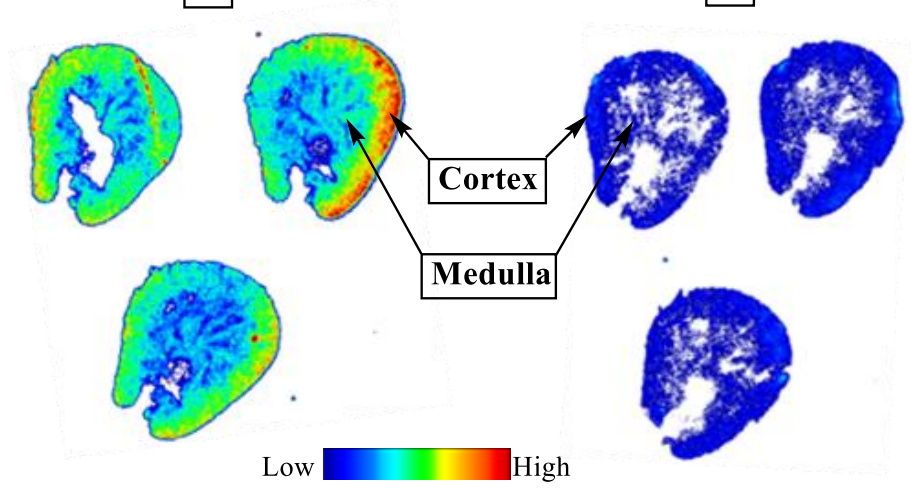

Figure 4. In vitro autoradiography of $\left[{ }^{18} \mathrm{~F}\right] \mathbf{1}$ in transversal cryosections of the mouse kidney. Total (A) and non-specific (B) binding of $\sim 1 \mathrm{nM}\left[{ }^{18} \mathrm{~F}\right] 1$ obtained without and with co-incubation with $10 \mu \mathrm{M}$ $\alpha$-CCA-Na.

To investigate the stability of $\left[{ }^{18} \mathrm{~F}\right] \mathbf{1}$ in vivo, samples of plasma and brain homogenates obtained from CD-1 mice at 30 min after intravenous injection of the radiotracer were analyzed for radiometabolites by using reversed-phase and micellar (MLC) radio-HPLC. MLC allows a direct injection of the samples into the HPLC system without the elimination of the tissue matrix as already described $[47,48]$. In general, the results obtained with both methods are comparable and the analyses revealed solely intact radiotracer and no detectable radiometabolites in plasma (Figure 5A-B) and brain (Supplementary Data, Figure S2) samples. Notably, in both samples two peaks a/b were detected by analytical HPLC (Figure 5/Figure S2) which are supposed to represent the neutral and deprotonated form of the radiotracer $\left(\left[{ }^{18} \mathrm{~F}\right] \mathbf{1} \mathbf{a} / \mathbf{b}\right)$. This finding suggests that the analytical HPLC conditions do not reflect the physiological milieu at which the neutral compound fraction would be negligible according to the Henderson-Hasselbalch equation. Research into the speciation of 1 under analytical-chemical conditions is subject to a future investigation. 

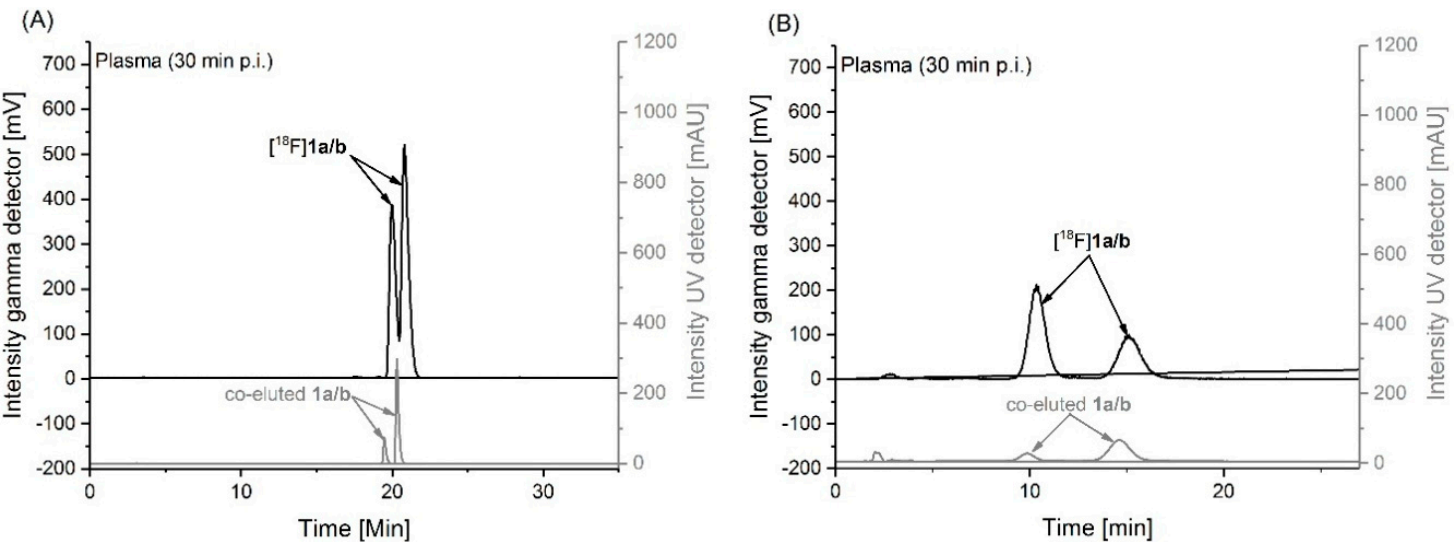

Figure 5. Analytical UV- and radio-HPLC chromatograms representing two peaks $\mathrm{a} / \mathrm{b}$ which are supposed to reflect the neutral and deprotonated form of the radiotracer $\left(\left[{ }^{18} \mathrm{~F}\right] \mathbf{1 a} / \mathbf{b}\right)$ in mouse plasma at 30 min p.i. measured under: (A) reversed phase (Reprosil-Pur C18-AQ, $250 \times 4.6 \mathrm{~mm}$, gradient with an eluent mixture of $\mathrm{ACN} / 20 \mathrm{mM} \mathrm{NH}_{4} \mathrm{OAc}$ (aq.), $370 \mathrm{~nm}, 1.0 \mathrm{~mL} / \mathrm{min}$ ), and (B) micellar conditions (Reprosil-Pur C18-AQ, $250 \times 4.6 \mathrm{~mm}$, isocratic mode with water containing $50 \mathrm{mM}$ sodium dodecyl sulfate $/ 10 \mathrm{mM} \mathrm{NaHPO} 4,1.0 \mathrm{~mL} / \mathrm{min})$.

Pharmacokinetic studies of $\left[{ }^{18} \mathrm{~F}\right] \mathbf{1}$ were performed by dynamic PET imaging in mouse using a dedicated small animal PET/MR camera. The target-specificity of $\left[{ }^{18} \mathrm{~F}\right] \mathbf{1}$ was investigated by pre-administration of the blocking compound $\alpha$-CCA-Na. Maximum intensity projections of PET studies from a representative control and $\alpha$-CCA-Na treated animals and time-activity curves (TACs) from tissues of interest are presented in Figure $6 .\left[{ }^{18} \mathrm{~F}\right] \mathbf{1}$ cleared rapidly from the blood with an initial TAC peak standardized uptake value (SUV) of 7.3 and a SUV of 1.5 after $10 \mathrm{~min}$ followed by a slow blood clearance to a SUV of 0.9 after $60 \mathrm{~min}$ in the control group (Figure 6B). Pre-administration of the MCT inhibitor $\alpha$-CCA-Na resulted in an initial TAC peak SUV of 6.9 which was comparable to the control group, whereas a higher SUV of 3.5 after $10 \mathrm{~min}$ and a SUV of 1.5 was reached after $60 \mathrm{~min}$ p.i., reflecting higher availability of the radiotracer in the blood (Figure 6B). This is expected to be caused by blocking the uptake of $\left[{ }^{18} \mathrm{~F}\right] \mathbf{1}$ in peripheral organs in vivo. In comparison to the control conditions, the pre-administration of $\alpha$-CCA-Na significantly reduced the activity accumulation in the MCT1-expressing renal cortex [46] throughout the whole imaging period, which is shown by the SUV ratio (SUVR) of kidney cortex-to-blood (Figure 6D). Furthermore, the displacement study revealed 39.2\% drop of the SUV, 20 min after i.v. injection of $\alpha$-CCA-Na (Figure 6E), which implicates a reversible tissue uptake of $\left[{ }^{18} \mathrm{~F}\right] \mathbf{1}$ in the kidney cortex. Nevertheless, further studies are needed to clarify the exact mechanism of the radiotracer uptake. Regarding liver, where the highly expressed MCT1 transports L-lactate into the parenchymal cells for gluconeogenesis [1], a constantly increasing accumulation of activity can be observed under both control and blocking conditions, although at lower values under pre-administration of $\alpha$-CCA-Na (Figure 6C).

Taking into consideration the high activity concentrations persistently accumulated in the kidney and liver, the blocking effect of $\alpha$-CCA-Na in both tissues will result in a strong increase in the fraction of available tracer in blood as reflected by the higher SUV in blood observed in the blocking experiments (Area Under the Curve $(\mathrm{AUC})_{0-60 \mathrm{~min}}=140 \mathrm{SUV} \times$ minutes $)$ compared to the control experiments $\left(\mathrm{AUC}_{0-60 \mathrm{~min}}=75 \mathrm{SUV} \times\right.$ minutes$)$. 
(A)

$$
\begin{array}{cc} 
& {\left[{ }^{18} \mathrm{~F}\right] \mathbf{1} \quad\left[{ }^{18} \mathrm{~F}\right] \mathbf{1}} \\
+ \text { vehicle } & +\alpha-\mathrm{CCA}-\mathrm{Na}
\end{array}
$$

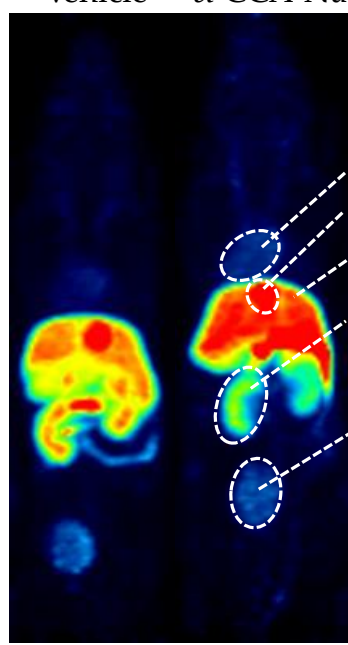

SUV

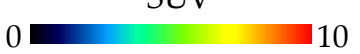

(B)

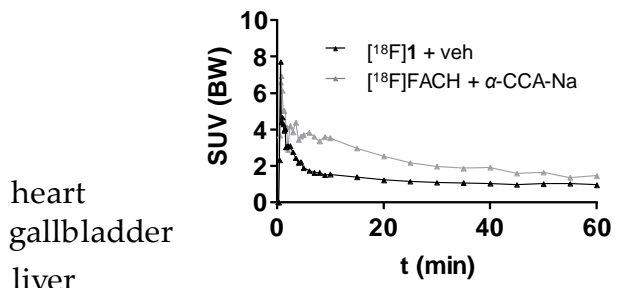

(D)

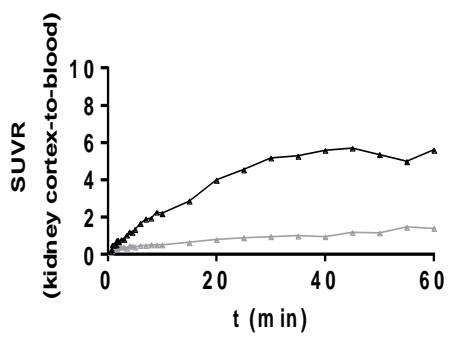

left kidney

bladder
(C)

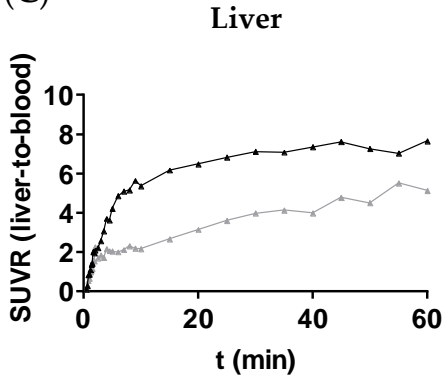

E)

Figure 6. (A) Maximum intensity projections (MIPs) of small animal positron emission tomography (PET) images (45-60 min p.i., $\mathrm{n}=1$ ) of female CD-1 mice depicting the differential distribution of $\left[{ }^{18} \mathrm{~F}\right] \mathbf{1}$ in peripheral organs without and with pre-administration of $\alpha$-CCA-Na; (B-D) Time-activity curves representing the SUV of blood, as well as the standardized uptake value (SUV) ratio (SUVR) from liver-to-blood and kidney cortex-to-blood; (E) displacement study: i.v. application of $\alpha$-CCA-Na 20 min after tracer injection $(n=2)$, MIPs of the left kidney (left: 15-20 min p.i. and right: 45-60 min p.i.).

According to Figure $7 \mathrm{~A},\left[{ }^{18} \mathrm{~F}\right] \mathbf{1}$ shows a similar brain uptake as $\left[{ }^{18} \mathrm{~F}\right] \mathrm{FACH}$ despite a somewhat higher lipophilicity. Note, however, that this is in accordance with our ACD predictions regarding both $\log \mathrm{D}_{7.4}$ and $\log K_{\mathrm{BB}}$ values (Table 1$)$. The slightly higher lipophilicity $\left(\log K_{\mathrm{ow}}\right.$ and $\left.\log \mathrm{D}_{7.4}\right)$ of $\mathbf{1}$ is accompanied by a slightly lower BBB penetration $\left(\log K_{\mathrm{BB}}\right)$, demonstrating further that passive brain uptake is not governed alone by $\log \mathrm{D}_{7.4}$. Moreover, a selective uptake into a particular brain region could not be verified for both radiotracers (Figure 7, C and D). The SUVR (brain-to-blood) of [ $\left.{ }^{18} \mathrm{~F}\right] \mathbf{1}$ was reduced by $\alpha$-CCA-Na by only $25 \%$ compared to the control animal (Figure $7 \mathrm{~B}$ ), which is much less than the reduction of kidney uptake and indicates that the uptake of $\left[{ }^{18} \mathrm{~F}\right] \mathbf{1}$ into the brain is partially mediated by MCT1 expressed at the endothelial cells of the BBB [49,50], and partly by non-specific diffusion mediated by lipophilicity. 
Brain

(A)

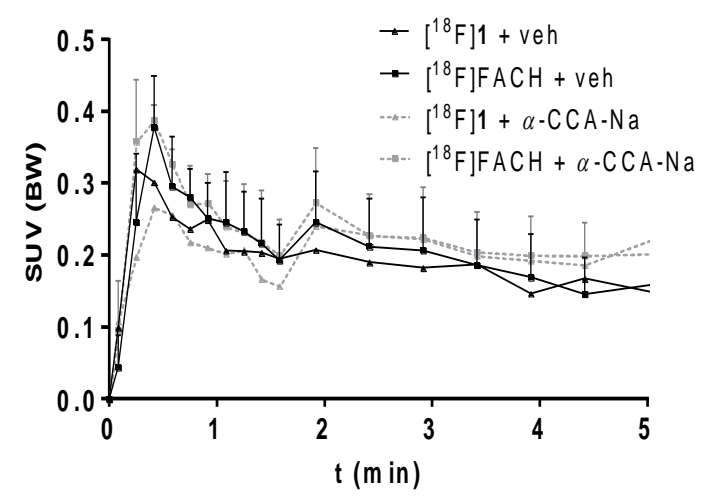

(C)

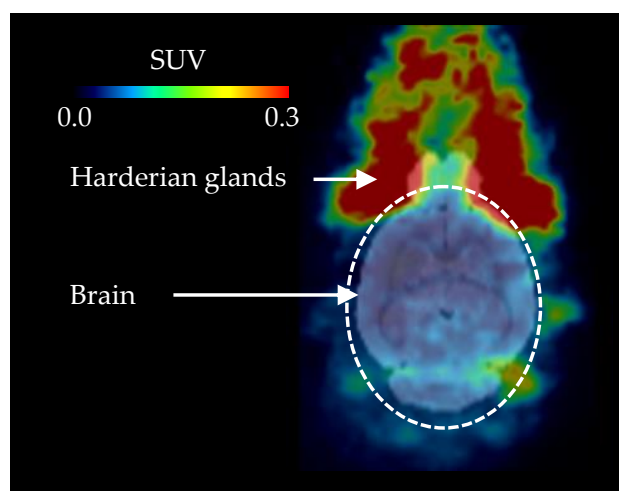

(B)

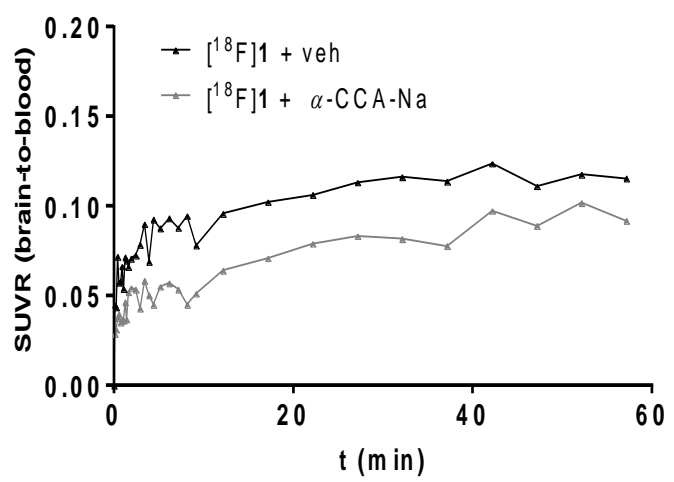

(D)

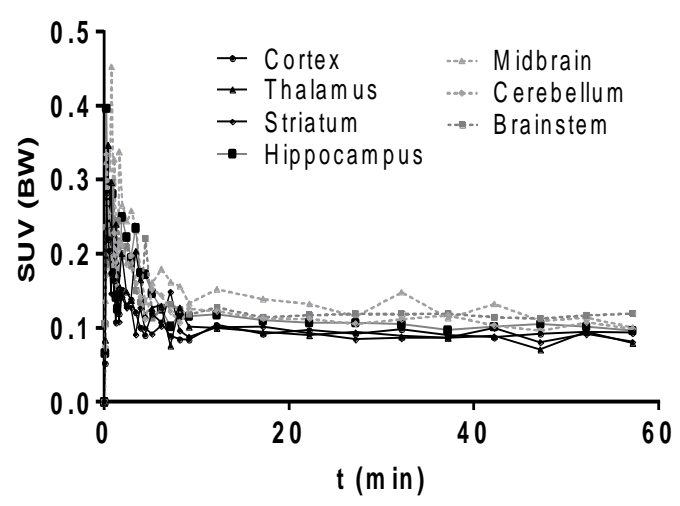

Figure 7. (A) Time-activity curve of $\left[{ }^{18} \mathrm{~F}\right] \mathbf{1}(\mathrm{n}=1)$ and $\left[{ }^{18} \mathrm{~F}\right] \mathrm{FACH}(\mathrm{n}=3)$ representing the SUVs without and with pre-administration of $\alpha$-CCA-Na; (B) The SUVR of $\left[{ }^{18} \mathrm{~F}\right] \mathbf{1}$ showing the brain to blood uptake ratio $(\mathrm{n}=1) ;(\mathrm{C})$ horizontal section of representative PET image (averaged time frames from 0-60 min p.i.) of mouse head; (D) SUVs of different brain regions over time after injection of $\left[{ }^{18} \mathrm{~F}\right] \mathbf{1}$.

Brain capillary endothelial cells are tightly bound to each other and constitute the permeability barrier of the BBB/Neurovascular Unit (NVU), which serves to restrict the transport of compounds into the brain. The permeation of compounds across the BBB/NVU is determined not only by lipophilicity, ionic feature and molecular size, but also by various transporters expressed on the endothelial cell membrane [51]. For example, the radiotracer $\left[{ }^{11} \mathrm{C}\right]$ choline has initially been demonstrated a comparably low brain accumulation with $0.08 \%$ of injected dose/g brain $(\% \mathrm{ID} / \mathrm{g}) 10 \mathrm{~min}$ after injection in mice [52] and $0.15 \% \mathrm{ID} / \mathrm{g}$ at $15 \mathrm{~min}$ after injection in rats [53]. This low uptake of $\left[{ }^{11} \mathrm{C}\right]$ choline from blood is mediated by a choline-specific transport system of brain endothelial cell membranes [54]. Despite the low BBB/NVU permeability of $\left[{ }^{11} \mathrm{C}\right]$ choline, it is a clinically relevant radiopharmaceutical for brain tumor imaging with high and specific accumulation in proliferating cancer cells $[55,56]$. Notably, in our control experiment using the MCT radioligand $\left[{ }^{18} \mathrm{~F}\right] \mathbf{1}$, a moderate brain accumulation of $0.4 \% \mathrm{ID} / \mathrm{g}$ at 10 min after injection was observed. It has been shown that MCT1 is expressed along with MCT4 in the cerebral microvascular endothelium cells suggesting a key role in transporting endogenous monocarboxylates into and out of the brain $[50,57,58]$. Together with the important role of MCT1 and MCT4 for glioma metabolism $[5,32,33,59]$, it provides evidence that $\left[{ }^{18} \mathrm{~F}\right] \mathrm{FACH}$ and/or $\left[{ }^{18} \mathrm{~F}\right] \mathbf{1}$ might be suitable for brain tumor imaging. 


\section{Materials and Methods}

\subsection{Organic Synthesis}

The syntheses of 1, $\mathbf{2}$ and $\mathbf{1 5}$ (nitro precursor) were implemented by slight modifications of the previously reported procedures [26,36-39]. All final compounds described here meet the purity requirements determined by HPLC, NMR, and HR-MS analyses.

\subsubsection{General Information}

Unless otherwise noted, moisture-sensitive reactions were conducted under dry nitrogen or argon. $\mathrm{Pd}(\mathrm{OAc})_{2}$, Xantphos (4,5-bis(diphenylphosphino)-9,9-dimethylxanthene), and $\mathrm{Cs}_{2} \mathrm{CO}_{3}$ were purchased from Sigma-Aldrich (SIGMA-ALDRICH Chemie GmbH, Schnelldorf, Germany). Other chemicals and reagents were purchased from commercial sources and were used without further purification. For thin-layer chromatography (TLC), Silica gel 60 F254 plates (Merck KGaA, Darmstadt, Germany) were used. Flash chromatography $\left(\mathrm{f}_{\mathrm{c}}\right)$ was performed using Silica gel 60, 40-64 $\mu \mathrm{m}$ (Merck). Room temperature was $21{ }^{\circ} \mathrm{C} .{ }^{1} \mathrm{H},{ }^{13} \mathrm{C}$, and ${ }^{19} \mathrm{~F}$ spectra were recorded on Varian "MERCURY plus 300/400" (Varian, Palo Alto, CA, USA) and Bruker Advance DRX-400 (Bruker, Billerica, MA, USA); $\delta$ in ppm related to tetramethylsilane; coupling constants $(J)$ are given with $0.1 \mathrm{~Hz}$ resolution. Multiplicities of NMR signals are indicated as follows: s (singlet), $d$ (doublet), $t$ (triplet), q (quartet), $m$ (multiplet), $\mathrm{dd}$ (doublet of doublets), ddd (doublet of doublet of doublets), $\mathrm{td}$ (triplet of doublets), dq (doublet of quartets) and h (hexet (sextet)). High-resolution mass spectra (HR-MS) were recorded on an FT-ICR APEX II spectrometer (Bruker Daltonics; Bruker Corporation, Billerica, MA, USA) using electrospray ionization (ESI) in positive ion mode.

\subsubsection{General Procedures}

General Procedure A: The Buchwald-Hartwig Aryl Amination Reaction.

Substituted halide (2.5 mmol, 1.0 eq.) was dissolved in dry dioxane $(10 \mathrm{~mL})$ in a dry Schlenk tube, under an argon atmosphere. $\mathrm{Pd}(\mathrm{OAc})_{2}(28 \mathrm{mg}, 0.125 \mathrm{mmol}, 0.05$ eq. $)$, Xantphos (72 mg, $0.125 \mathrm{mmol}$, 0.05 eq.), and $\mathrm{Cs}_{2} \mathrm{CO}_{3}(2.04 \mathrm{~g}, 6.25 \mathrm{mmol}, 2.5$ eq.) were added afterwards and the mixture was stirred at $75{ }^{\circ} \mathrm{C}$. After $20 \mathrm{~min}$, amine ( $3.0 \mathrm{mmol}, 1.2 \mathrm{eq}$.) was added, and the reaction mixture was conducted at $105^{\circ} \mathrm{C}$ under an argon atmosphere. The reaction monitored by TLC and it was completed in $30 \mathrm{~min}$. After cooling to room temperature, the reaction mixture was diluted with diethyl ether $\left(\mathrm{Et}_{2} \mathrm{O}\right)$, the solids were filtered and washed by $\mathrm{Et}_{2} \mathrm{O}$. The solvents were evaporated under vacuum and the oily residue was then purified by column chromatography.

\section{General Procedure B}

To a solution of substituted amine (2.0 mmol, 1.0 eq.) in $N, N$-dimethylformamide (DMF, $10 \mathrm{~mL}$ ), $\mathrm{NaH}$ (26.0 mmol of a 60\% dispersion in mineral oil, 13.0 eq.) was added in small portions under argon. 1-Iodopropane $(0.488 \mathrm{~mL}, 5.0 \mathrm{mmol}, 2.5 \mathrm{eq}$.) was thereafter added to the mixture. After stirring for $1 \mathrm{~h}$ at room temperature, the mixture was slowly poured on an ice-water mixture and stirred for $5 \mathrm{~min}$. The mixture was extracted with ethyl acetate (EtOAc, $2 \times 25 \mathrm{~mL}$ ), the extracts were combined, dried with anhydrous $\mathrm{MgSO}_{4}$, and concentrated by evaporation of the solvents under vacuum. The residue was then purified by column chromatography.

General Procedure C

$\mathrm{POCl}_{3}(1.03 \mathrm{~mL}, 11.0 \mathrm{mmol}, 1.1$ eq.) was added dropwise to DMF (4.6 mL, $60.0 \mathrm{mmol}, 6.0$ eq.) at $0{ }^{\circ} \mathrm{C}$ and the mixture was stirred $30 \mathrm{~min}$ at room temperature. To this solution, $N, N$-disubstituted aniline (10.0 mmol, 1.0 eq.) was added and the reaction mixture was heated up to $80^{\circ} \mathrm{C}$. After $2-4 \mathrm{~h}$, the reaction was quenched by addition of a mixture of ice water, stirred for additional $5 \mathrm{~min}$. The $\mathrm{pH}$ was thereafter adjusted to $6-7$ by using aqueous $1 \mathrm{M} \mathrm{NaOH}$. The residue was extracted with chloroform 
$\left(\mathrm{CHCl}_{3}, 3 \times 15 \mathrm{~mL}\right)$, and the organic phases were combined, washed with $\mathrm{H}_{2} \mathrm{O}$ and brine. The extracts were dried with anhydrous $\mathrm{MgSO}_{4}$ and the corresponding $\mathrm{N}, \mathrm{N}$-disubstituted benzaldehyde was purified by column chromatography after evaporation of the solvents.

To a solution of the substituted benzaldehyde (5.0 mmol, 1.0 eq.) in $20 \mathrm{~mL}$ acetonitrile (ACN), cyanoacetic acid $(0.991 \mathrm{~mL}, 15.0 \mathrm{mmol}, 3.0$ eq.) and piperidine $(0.494 \mathrm{~mL}, 5.0 \mathrm{mmol}, 1.0$ eq.) were added and refluxed overnight at $85^{\circ} \mathrm{C}$. Upon the completion of the reaction, as judged by TLC, the above solution was poured into a mixture of $3 \mathrm{M} \mathrm{HCl}(10 \mathrm{~mL})$ on ice. The solution was stirred for 30 min and the solids were filtered using a Büchner funnel and washed with ice-cold ACN. The solid was afterwards poured into adequate amount of $n$-hexane and stirred for $15 \mathrm{~min}$ to remove the remaining aldehyde. The final compounds were obtained in pure form after filtration of the solids and consequent washing with $n$-hexane.

6-Fluoro-N-(3-methoxyphenyl)pyridin-2-amine (5). The reaction was carried out according to the general procedure A. Column chromatography: silica, EtOAc/ $n$-hexane, 1:2; Yellow oil: $96 \%$ yield; TLC: (silica gel, EtOAc/n-hexane, 2:1), $\mathrm{R}_{\mathrm{f}}=0.8 .{ }^{1} \mathrm{H}$ NMR $\left(300 \mathrm{MHz}, \mathrm{CDCl}_{3}\right) \delta 7.56(\mathrm{q}, J=8.0 \mathrm{~Hz}, 1 \mathrm{H}), 7.25(\mathrm{~m}$, $1 \mathrm{H}), 6.97(\mathrm{t}, J=2.2 \mathrm{~Hz}, 1 \mathrm{H}), 6.90(\mathrm{ddd}, J=8.0,2.1,0.8 \mathrm{~Hz}, 1 \mathrm{H}), 6.73(\mathrm{dd}, J=8.1,2.3 \mathrm{~Hz}, 1 \mathrm{H}), 6.66$ $(\mathrm{ddd}, J=8.3,2.4,0.8 \mathrm{~Hz}, 1 \mathrm{H}), 6.33(\mathrm{dd}, J=7.8,2.2 \mathrm{~Hz}, 1 \mathrm{H}), 3.83(\mathrm{~s}, 3 \mathrm{H}) ;{ }^{13} \mathrm{C} \mathrm{NMR}\left(75 \mathrm{MHz}, \mathrm{CDCl}_{3}\right) \delta$ $162.87(\mathrm{~d}, J=238.2 \mathrm{~Hz}), 160.49,154.92(\mathrm{~d}, J=16.1 \mathrm{~Hz}), 142.12(\mathrm{~d}, J=8.4 \mathrm{~Hz}), 140.82,130.03,113.09$, $108.87,106.67,104.30(\mathrm{~d}, J=4.2 \mathrm{~Hz}), 98.29(\mathrm{~d}, J=36.1 \mathrm{~Hz}), 55.27 ;{ }^{19} \mathrm{~F}$ NMR $\left(282 \mathrm{MHz}, \mathrm{CDCl}_{3}\right) \delta-69.08$ $(\mathrm{d}, J=8.1 \mathrm{~Hz})$.

6-Fluoro-N-(3-methoxyphenyl)-N-propylpyridin-2-amine (6). The reaction was carried out according to the general procedure B. Column chromatography: silica, EtOAc/n-hexane, 1:3; Yellow oil: 95\% yield; TLC: (silica gel, EtOAc/n-hexane, 1:3), $\mathrm{R}_{\mathrm{f}}=0.75 .{ }^{1} \mathrm{H}$ NMR $\left(400 \mathrm{MHz}, \mathrm{CDCl}_{3}\right) \delta 7.35-7.27(\mathrm{~m}, 2 \mathrm{H}), 6.95-6.65$ $(\mathrm{m}, 3 \mathrm{H}), 6.12(\mathrm{td}, J=7.6,2.5 \mathrm{~Hz}, 2 \mathrm{H}), 3.85(\mathrm{~d}, J=7.6 \mathrm{~Hz}, 2 \mathrm{H}), 3.81(\mathrm{~s}, 3 \mathrm{H}), 1.66(\mathrm{~m}, 2 \mathrm{H}), 0.92(\mathrm{t}, J=7.4 \mathrm{~Hz}$, $3 \mathrm{H}) ;{ }^{13} \mathrm{C}$ NMR $\left(101 \mathrm{MHz}, \mathrm{CDCl}_{3}\right) \delta 162.85(\mathrm{~d}, J=234.7 \mathrm{~Hz}), 160.87,157.87(\mathrm{~d}, J=16.1 \mathrm{~Hz}), 145.82$, $140.72(\mathrm{~d}, J=8.3 \mathrm{~Hz}), 130.50,120.09,113.64,111.95,104.78(\mathrm{~d}, J=4.1 \mathrm{~Hz}), 95.17(\mathrm{~d}, J=37.4 \mathrm{~Hz}), 55.30$, 51.76, 21.05, 11.26; ${ }^{19} \mathrm{~F}$ NMR $\left(377 \mathrm{MHz}, \mathrm{CDCl}_{3}\right) \delta-69.25(\mathrm{~d}, J=8.3 \mathrm{~Hz})$.

6-Fluoro-N-(3-methoxyphenyl)-N-phenylpyridin-2-amine (7). The reaction was carried out according to the general procedure A. For this compound, higher amounts of $\mathrm{Pd}(\mathrm{OAc})_{2}(84 \mathrm{mg}, 0.375 \mathrm{mmol}, 0.15 \mathrm{eq}$.) and Xantphos ( $217 \mathrm{mg}, 0.375 \mathrm{mmol}, 0.15$ eq. $)$ were added stepwise $(3 \times 0.125 \mathrm{mmol})$ to the reaction mixture over $24 \mathrm{~h}$. Column chromatography: silica, EtOAc/n-hexane, 1:3; Milky oil: $46 \%$ yield; TLC: (silica gel, EtOAc/n-hexane, 1:3), $\mathrm{R}_{\mathrm{f}}=0.85 .{ }^{1} \mathrm{H}$ NMR $\left(400 \mathrm{MHz}, \mathrm{CDCl}_{3}\right) \delta 7.48(\mathrm{dt}, J=8.4,7.9 \mathrm{~Hz}, 1 \mathrm{H})$, 7.38-7.29 (m, 2H), 7.28-7.12 (m, 4H), $6.79(\mathrm{ddd}, J=7.9,2.0,0.9 \mathrm{~Hz}, 1 \mathrm{H}), 6.77-6.69(\mathrm{~m}, 2 \mathrm{H}), 6.50(\mathrm{ddd}$, $J=8.1,2.2,0.5 \mathrm{~Hz}, 1 \mathrm{H}), 6.34(\mathrm{ddd}, J=7.8,2.9,0.5 \mathrm{~Hz}, 1 \mathrm{H}), 3.75(\mathrm{~s}, 3 \mathrm{H}) ;{ }^{13} \mathrm{C} \mathrm{NMR}\left(101 \mathrm{MHz}, \mathrm{CDCl}_{3}\right) \delta$ $162.43(\mathrm{~d}, J=237.8 \mathrm{~Hz}), 160.49,157.50(\mathrm{~d}, J=15.1 \mathrm{~Hz}), 146.32,145.06,141.55(\mathrm{~d}, J=8.1 \mathrm{~Hz}), 130.02$, 129.39, 126.62, 125.23, 119.07, 112.63, 110.74, $109.10(\mathrm{~d}, J=4.5 \mathrm{~Hz}), 99.41(\mathrm{~d}, J=37.0 \mathrm{~Hz}), 55.29 ;{ }^{19} \mathrm{~F} \mathrm{NMR}$ $\left(377 \mathrm{MHz}, \mathrm{CDCl}_{3}\right) \delta-67.46(\mathrm{~d}, J=7.3 \mathrm{~Hz})$.

4-((6-Fluoropyridin-2-yl)(propyl)amino)-2-methoxybenzaldehyde (8). The reaction was carried out according to the general procedure $\mathrm{C}$. Column chromatography: silica, EtOAc/petroleum ether (PE), 1:2; Yellow oil: $57 \%$ yield; TLC: (silica gel, EtOAc/PE, 1:2), $\mathrm{R}_{\mathrm{f}}=0.55 .{ }^{1} \mathrm{H} \mathrm{NMR}\left(300 \mathrm{MHz}, \mathrm{CDCl}_{3}\right) \delta 10.35(\mathrm{~s}, 1 \mathrm{H})$, $7.82(\mathrm{~d}, J=8.4 \mathrm{~Hz}, 1 \mathrm{H}), 7.46(\mathrm{dt}, J=8.5,7.9 \mathrm{~Hz}, 1 \mathrm{H}), 6.88(\mathrm{ddd}, J=8.4,2.0,0.7 \mathrm{~Hz}, 1 \mathrm{H}), 6.82(\mathrm{~d}, J=1.9 \mathrm{~Hz}$, $1 \mathrm{H}), 6.55(\mathrm{ddd}, J=8.1,2.4,0.5 \mathrm{~Hz}, 1 \mathrm{H}), 6.30(\mathrm{ddd}, J=7.8,2.9,0.5 \mathrm{~Hz}, 1 \mathrm{H}), 3.98-3.89(\mathrm{~m}, 2 \mathrm{H}), 3.88(\mathrm{~s}, 3 \mathrm{H})$, $1.69(\mathrm{dq}, J=14.8,7.4 \mathrm{~Hz}, 2 \mathrm{H}), 0.94(\mathrm{t}, J=7.4 \mathrm{~Hz}, 3 \mathrm{H}) ;{ }^{13} \mathrm{C} \mathrm{NMR}\left(75 \mathrm{MHz}, \mathrm{CDCl}_{3}\right) \delta 189.19,163.05$ $(\mathrm{d}, J=244.3 \mathrm{~Hz}), 161.72,159.68(\mathrm{~d}, J=15.1 \mathrm{~Hz}), 149.95,140.12(\mathrm{~d}, J=8.1 \mathrm{~Hz}), 130.33,118.77,111.37$ $(\mathrm{d}, J=4.5 \mathrm{~Hz}), 106.62,100.47(\mathrm{~d}, J=37.0 \mathrm{~Hz}), 101.76,55.99,49.89,20.95,11.38 ;{ }^{19} \mathrm{~F}$ NMR $(282 \mathrm{MHz}$, $\left.\mathrm{CDCl}_{3}\right) \delta-68.09(\mathrm{~d}, J=8.6 \mathrm{~Hz})$.

4-((6-Fluoropyridin-2-yl)(phenyl)amino)-2-methoxybenzaldehyde (9). The reaction was carried out according to the general procedure C. Column chromatography: silica, EtOAc/n-hexane, 1:3; Yellow oil: $68 \%$ yield; TLC: (silica gel, EtOAc/ $n$-hexane, 1:3), $\mathrm{R}_{\mathrm{f}}=0.60 .{ }^{1} \mathrm{H}$ NMR $\left(300 \mathrm{MHz}, \mathrm{CDCl}_{3}\right) \delta 10.32(\mathrm{~s}, 1 \mathrm{H}), 7.73$ 
$(\mathrm{d}, J=8.5 \mathrm{~Hz}, 1 \mathrm{H}), 7.59(\mathrm{q}, J=8.0 \mathrm{~Hz}, 1 \mathrm{H}), 7.46-7.37(\mathrm{~m}, 2 \mathrm{H}), 7.33-7.25(\mathrm{~m}, 1 \mathrm{H}), 7.24-7.16(\mathrm{~m}, 2 \mathrm{H}), 6.78$ $(\mathrm{d}, J=2.0 \mathrm{~Hz}, 1 \mathrm{H}), 6.69(\mathrm{ddd}, J=8.5,2.0,0.8 \mathrm{~Hz}, 1 \mathrm{H}), 6.60(\mathrm{dd}, J=8.0,1.7 \mathrm{~Hz}, 1 \mathrm{H}), 6.54-6.46(\mathrm{~m}, 1 \mathrm{H})$, $3.77(\mathrm{~s}, 3 \mathrm{H}) ;{ }^{13} \mathrm{C}$ NMR $\left(75 \mathrm{MHz}, \mathrm{CDCl}_{3}\right) \delta 188.37,162.91(\mathrm{~d}, J=235.1 \mathrm{~Hz}), 162.63,156.61(\mathrm{~d}, J=14.9 \mathrm{~Hz})$, $152.14,144.37,142.13(\mathrm{~d}, J=8.1 \mathrm{~Hz}), 130.06,129.50,127.66,126.70,120.65,116.19,111.59(\mathrm{~d}, J=4.6 \mathrm{~Hz})$, $106.62,101.86(\mathrm{~d}, J=36.6 \mathrm{~Hz}), 55.60 ;{ }^{19} \mathrm{~F} \mathrm{NMR}\left(282 \mathrm{MHz}, \mathrm{CDCl}_{3}\right) \delta-66.92(\mathrm{~d}, J=8.5 \mathrm{~Hz})$.

(E)-2-Cyano-3-(4-((6-fluoropyridin-2-yl)(propyl)amino)-2-methoxyphenyl)acrylic Acid (1). The reaction was carried out according to the general procedure C. Yellow solid: $95 \%$ yield; TLC: (silica gel, $\mathrm{CHCl}_{3} / \mathrm{MeOH} /$ acetic acid $\left.(\mathrm{AcOH}), 95: 5: 0.1\right), \mathrm{R}_{\mathrm{f}}=0.60 .{ }^{1} \mathrm{H} \mathrm{NMR}\left(400 \mathrm{MHz}, \mathrm{CDCl}_{3} / \mathrm{CD}_{3} \mathrm{OD}\right) \delta 8.63$ $(\mathrm{s}, 1 \mathrm{H}), 8.30(\mathrm{~d}, J=8.7 \mathrm{~Hz}, 1 \mathrm{H}), 7.46(\mathrm{q}, J=8.2 \mathrm{~Hz}, 1 \mathrm{H}), 6.86(\mathrm{dd}, J=8.7,2.1 \mathrm{~Hz}, 1 \mathrm{H}), 6.74(\mathrm{~d}, J=2.1 \mathrm{~Hz}$, $1 \mathrm{H}), 6.59(\mathrm{dd}, J=8.1,2.2 \mathrm{~Hz}, 1 \mathrm{H}), 6.31(\mathrm{dd}, J=7.8,2.8 \mathrm{~Hz}, 1 \mathrm{H}), 3.93-3.86(\mathrm{~m}, 2 \mathrm{H}), 3.80(\mathrm{~s}, 3 \mathrm{H})$, $1.65(\mathrm{~h}, J=7.4 \mathrm{~Hz}, 2 \mathrm{H}), 0.90(\mathrm{t}, J=7.4 \mathrm{~Hz}, 3 \mathrm{H}) ;{ }^{13} \mathrm{C} \mathrm{NMR}\left(101 \mathrm{MHz}, \mathrm{CDCl}_{3} / \mathrm{CD}_{3} \mathrm{OD}\right) \delta 164.86$, $162.72(\mathrm{~d}, J=237.5 \mathrm{~Hz}), 160.52,156.27(\mathrm{~d}, J=15.2 \mathrm{~Hz}), 151.55,148.32,141.46(\mathrm{~d}, J=8.3 \mathrm{~Hz}), 133.13$, $130.43,116.63,116.39,108.28(\mathrm{~d}, J=4.3 \mathrm{~Hz}), 106.26,100.01,99.02(\mathrm{~d}, J=36.9 \mathrm{~Hz}), 55.72,51.83,21.14$, $11.14 ;{ }^{19} \mathrm{~F} \mathrm{NMR}\left(376 \mathrm{MHz}, \mathrm{CDCl}_{3} / \mathrm{CD}_{3} \mathrm{OD}\right) \delta-68.23(\mathrm{dt}, J=8.3,2.2 \mathrm{~Hz}$ ).HR-MS (ESI) $m / z$ :calcd. for $\left[\mathrm{C}_{18} \mathrm{H}_{17} \mathrm{FN}_{3} \mathrm{O}\right]^{+}=310.1350$; found $=310.1332\left[\mathrm{M}-\mathrm{CO}_{2} \mathrm{H}\right]^{+}$.

(E)-2-Cyano-3-(4-((6-fluoropyridin-2-yl)(phenyl)amino)-2-methoxyphenyl)acrylic Acid (2). The reaction was carried out according to the general procedure C. Orange solid: $98 \%$ yield; TLC: (silica gel, $\left.\left.\mathrm{CHCl}_{3} / \mathrm{MeOH} / \mathrm{AcOH}\right), 95: 5: 0.1\right), \mathrm{R}_{\mathrm{f}}=0.75 .{ }^{1} \mathrm{H} \mathrm{NMR}\left(400 \mathrm{MHz}, \mathrm{CDCl}_{3}\right) \delta 8.75(\mathrm{~s}, 1 \mathrm{H}), 8.37(\mathrm{~d}, J=8.8 \mathrm{~Hz}$, $1 \mathrm{H}), 7.65(\mathrm{q}, J=8.0 \mathrm{~Hz}, 1 \mathrm{H}), 7.47(\mathrm{t}, J=7.7 \mathrm{~Hz}, 2 \mathrm{H}), 7.41-7.17(\mathrm{~m}, 3 \mathrm{H}), 6.80(\mathrm{~d}, J=1.9 \mathrm{~Hz}, 1 \mathrm{H}), 6.73$ $(\mathrm{dd}, J=8.8,1.9 \mathrm{~Hz}, 1 \mathrm{H}), 6.69-6.61(\mathrm{~m}, 1 \mathrm{H}), 6.58(\mathrm{dd}, J=7.9,2.7 \mathrm{~Hz}, 1 \mathrm{H}), 3.79(\mathrm{~s}, 3 \mathrm{H}),{ }^{13} \mathrm{C} \mathrm{NMR}(101 \mathrm{MHz}$, $\left.\mathrm{CDCl}_{3}\right) \delta 167.91,162.31(\mathrm{~d}, J=240.5 \mathrm{~Hz}), 160.76,156.25(\mathrm{~d}, J=14.6 \mathrm{~Hz}), 152.17,149.60,143.99,142.34$ $(\mathrm{d}, J=8.2 \mathrm{~Hz}), 130.35,130.24,127.87,127.16,116.26,115.94,115.58,112.29(\mathrm{~d}, J=4.5 \mathrm{~Hz}), 105.47,102.54$ $(\mathrm{d}, J=36.5 \mathrm{~Hz}), 97.31,55.82 ;{ }^{19} \mathrm{~F} \mathrm{NMR}\left(377 \mathrm{MHz}, \mathrm{CDCl}_{3}\right) \delta-66.88(\mathrm{~d}, J=8.2 \mathrm{~Hz}) . H R-M S(E S I) \mathrm{m} / \mathrm{z}$ : calcd. for $\left[\mathrm{C}_{21} \mathrm{H}_{15} \mathrm{FN}_{3} \mathrm{O}\right]^{+}=344.1194$; found $=344.1180\left[\mathrm{M}-\mathrm{CO}_{2} \mathrm{H}\right]^{+}$.

N-(3-Methoxyphenyl)-6-nitropyridin-2-amine (12). The reaction was carried out according to the general procedure A. Column chromatography: silica, EtOAc/n-hexane, 1:1; Yellow solid: $80 \%$ yield; TLC: (silica gel, EtOAc/n-hexane, 1:1), $\mathrm{R}_{\mathrm{f}}=0.65 .{ }^{1} \mathrm{H} \mathrm{NMR}\left(400 \mathrm{MHz}, \mathrm{CDCl}_{3}\right) \delta 7.78-7.70(\mathrm{~m}, 1 \mathrm{H}), 7.63$ $(\mathrm{dd}, J=7.6,0.6 \mathrm{~Hz}, 1 \mathrm{H}), 7.31-7.24(\mathrm{~m}, 1 \mathrm{H}), 7.23-7.19(\mathrm{~m}, 1 \mathrm{H}), 7.14(\mathrm{dd}, J=8.2,0.6 \mathrm{~Hz}, 1 \mathrm{H}), 6.88(\mathrm{ddd}$, $J=7.9,2.0,0.8 \mathrm{~Hz}, 1 \mathrm{H}), 6.71(\mathrm{ddd}, J=8.3,2.5,0.8 \mathrm{~Hz}, 1 \mathrm{H}), 3.86(\mathrm{~s}, 3 \mathrm{H}) ;{ }^{13} \mathrm{C} \mathrm{NMR}\left(101 \mathrm{MHz}, \mathrm{CDCl}_{3}\right) \delta$ $160.29,155.31,155.06,140.46,139.94,129.79,114.77,112.21,109.24,107.35,105.65,55.16$.

$\mathrm{N}$-(3-Methoxyphenyl)-6-nitro-N-propylpyridin-2-amine (13). The reaction was carried out according to the general procedure B. Column chromatography: silica, EtOAc/n-hexane, 1:3; Yellow oil: $93 \%$ yield; TLC: (silica gel, EtOAc/n-hexane, 1:3), $\mathrm{R}_{\mathrm{f}}=0.70 .{ }^{1} \mathrm{H}$ NMR $\left(400 \mathrm{MHz}, \mathrm{CDCl}_{3}\right) \delta 7.53-7.29(\mathrm{~m}, 3 \mathrm{H})$, $6.88(\mathrm{dd}, J=8.3,2.3 \mathrm{~Hz}, 1 \mathrm{H}), 6.82(\mathrm{~d}, J=7.9 \mathrm{~Hz}, 1 \mathrm{H}), 6.79-6.68(\mathrm{~m}, 1 \mathrm{H}), 6.59(\mathrm{~d}, J=8.2 \mathrm{~Hz}, 1 \mathrm{H}), 3.95$ $(\mathrm{t}, J=7.4 \mathrm{~Hz}, 2 \mathrm{H}), 3.82(\mathrm{~s}, 3 \mathrm{H}), 1.69(\mathrm{~h}, J=7.4 \mathrm{~Hz}, 2 \mathrm{H}), 0.95(\mathrm{t}, J=7.4 \mathrm{~Hz}, 3 \mathrm{H}) ;{ }^{13} \mathrm{C} \mathrm{NMR}(101 \mathrm{MHz}$, $\left.\mathrm{CDCl}_{3}\right) \delta 161.44,157.92,156.25,145.36,139.22,131.23,120.24,114.28,113.93,112.86,105.78,55.72,52.38$, $21.21,11.68$.

2-Methoxy-4-((6-nitropyridin-2-yl)(propyl)amino)benzaldehyde (14). The reaction was carried out according to the general procedure $\mathrm{C}$. Column chromatography: silica, EtOAc/PE, 1:2; Yellow oil: 92\% yield; TLC: (silica gel, EtOAc/PE, 1:2), $\mathrm{R}_{\mathrm{f}}=0.60 .{ }^{1} \mathrm{H}$ NMR $\left(400 \mathrm{MHz}, \mathrm{CDCl}_{3}\right) \delta 10.40(\mathrm{~s}, 1 \mathrm{H}), 7.89(\mathrm{~d}, J=8.3 \mathrm{~Hz}, 1 \mathrm{H})$, $7.63-7.53(\mathrm{~m}, 2 \mathrm{H}), 6.94-6.89(\mathrm{~m}, 2 \mathrm{H}), 6.88(\mathrm{~d}, J=1.9 \mathrm{~Hz}, 1 \mathrm{H}), 4.03(\mathrm{t}, J=7.4 \mathrm{~Hz}, 2 \mathrm{H}), 3.91(\mathrm{~s}, 3 \mathrm{H}), 1.74$ (h, $J=7.4 \mathrm{~Hz}, 2 \mathrm{H}), 0.97(\mathrm{t}, J=7.4 \mathrm{~Hz}, 3 \mathrm{H}) ;{ }^{13} \mathrm{C} \mathrm{NMR}\left(101 \mathrm{MHz}, \mathrm{CDCl}_{3}\right) \delta 188.37,163.12,156.66,155.98$, $151.33,139.56,130.32,122.69,118.05,115.38,108.86,107.32,55.84,52.30,21.08,11.38$.

(E)-2-Cyano-3-(2-methoxy-4-((6-nitropyridin-2-yl)(propyl)amino)phenyl)acrylic Acid (15). The reaction was carried out according to the general procedure C. Yellow solid: $>98 \%$ yield; TLC: (silica gel, $\left.\left.\mathrm{CHCl}_{3} / \mathrm{MeOH} / \mathrm{AcOH}\right), 95: 5: 0.1\right), \mathrm{R}_{\mathrm{f}}=0.70 .{ }^{1} \mathrm{H}$ NMR $\left(400 \mathrm{MHz}, \mathrm{CDCl}_{3} / \mathrm{CD}_{3} \mathrm{OD}\right) \delta 8.62(\mathrm{~s}, 1 \mathrm{H}), 8.30$ $(\mathrm{d}, J=8.5 \mathrm{~Hz}, 1 \mathrm{H}), 7.58(\mathrm{t}, J=7.9 \mathrm{~Hz}, 1 \mathrm{H}), 7.51(\mathrm{~d}, J=7.6 \mathrm{~Hz}, 1 \mathrm{H}), 6.92(\mathrm{~d}, J=8.3 \mathrm{~Hz}, 1 \mathrm{H}), 6.89(\mathrm{dd}, J=8.6$, $1.7 \mathrm{~Hz}, 1 \mathrm{H}), 6.80(\mathrm{~d}, J=1.5 \mathrm{~Hz}, 1 \mathrm{H}), 3.98(\mathrm{t}, J=7.4 \mathrm{~Hz}, 2 \mathrm{H}), 3.82(\mathrm{~s}, 3 \mathrm{H}), 1.68(\mathrm{~h}, J=7.4 \mathrm{~Hz}, 2 \mathrm{H}), 0.91$ 
$(\mathrm{t}, J=7.3 \mathrm{~Hz}, 3 \mathrm{H}) ;{ }^{13} \mathrm{C} \mathrm{NMR}\left(101 \mathrm{MHz}, \mathrm{CDCl}_{3} / \mathrm{CD}_{3} \mathrm{OD}\right) \delta 164.39,160.51,156.43,155.70,150.30,148.24$, 139.62, 130.62, 118.14, 117.66, 116.35, 115.78, 107.90, 107.54, 101.63, 55.82, 52.13, 20.95, 11.16. HR-MS (ESI) $m / z$ calcd. for $\left[\mathrm{C}_{18} \mathrm{H}_{17} \mathrm{~N}_{4} \mathrm{O}_{3}\right]^{+\cdot}=337.1295$; found $=337.1283\left[\mathrm{M}-\mathrm{CO}_{2} \mathrm{H}\right]^{+}$.

\subsection{Assessment of the MCT1 Inhibition by $\left[{ }^{14}\right.$ C]lactate Uptake Assay}

Inhibition of the MCT1-mediated lactate transport was determined using the rat brain endothelial cell line (RBE4, a gift from F. Roux research group [40]) as previously described [26]. PCR analysis and Western Blot demonstrated that only the MCT1 isoform is expressed by RBE4 cells.

\subsection{Radiochemistry}

\subsubsection{General Methods}

No-carrier-added $\left[{ }^{18} \mathrm{~F}\right]$ fluoride was produced via the $\left[{ }^{18} \mathrm{O}(\mathrm{p}, \mathrm{n}){ }^{18} \mathrm{~F}\right]$ nuclear reaction by irradiation of an $\left[{ }^{18} \mathrm{O}\right] \mathrm{H}_{2} \mathrm{O}$ target (Hyox 18 enriched water, Rotem Industries Ltd., Arava, Israel) on a Cyclone 18/9 (IBA RadioPharma Solutions, Lourain-La-Neuve, Belgium) with fixed energy proton beam using Nirta [ $\left.{ }^{18} \mathrm{~F}\right]$ fluoride XL target. Radio thin layer chromatography (radio-TLC) was performed on silica gel (ALUGRAM SIL G/UV254, Machery-Nagel, Düren, Germany) pre-coated plates with a mixture of dichloromethane (DCM)/MeOH (4:1) as eluent. The plates were exposed to storage phosphor screens (BAS IP MS 2025 E, GE Healthcare Europe GmbH, Freiburg, Germany) and recorded using the Amersham Typhoon RGB Biomolecular Imager (GE Healthcare Life Sciences). Images were quantified with the ImageQuant TL8.1 software (GE Healthcare Life Sciences).

Analytical chromatographic separations were performed on a JASCO LC-2000 system, incorporating a PU-2080Plus pump, AS-2055Plus auto injector (100 $\mu \mathrm{L}$ sample loop), and a UV-2070Plus detector coupled with a gamma radioactivity HPLC flow detector (Gabi Star, raytest Isotopenmessgeräte $\mathrm{GmbH}$, Straubenhardt, Germany). Data analysis was performed with the Galaxy chromatography software (version 1.10.0.5590, Agilent Technologies Deutschland GmbH, Waldbronn, Germany) using the chromatograms obtained at 254 and $370 \mathrm{~nm}$. Reprosil-Pur C18-AQ column $(250 \times 4.6 \mathrm{~mm} ; 5 \mu \mathrm{m}$; Dr. Maisch HPLC GmbH; Ammerbuch-Entingen, Germany) with an eluent mixture of ACN/20 mM $\mathrm{NH}_{4} \mathrm{OAc}$ (aq., pH 6.8) and a flow of $1.0 \mathrm{~mL} / \mathrm{min}$ were used (gradient: eluent A $10 \% \mathrm{ACN} / 20 \mathrm{mM}$ $\mathrm{NH}_{4} \mathrm{OAc}$ (aq.); eluent B 90\% ACN/20 mM NH${ }_{4} \mathrm{OAc}$ (aq.); 0-5 min 100\% A, 5-20 min up to 62\% B, 20-21 min up to $100 \% \mathrm{~B}, 21-26 \mathrm{~min} 100 \% \mathrm{~B}, 26-27 \mathrm{~min}$ up to $100 \% \mathrm{~A}, 27-35 \mathrm{~min} 100 \% \mathrm{~A}$; isocratic: $30 \%$ $\mathrm{MeOH} / 20 \mathrm{mM} \mathrm{NH}_{4} \mathrm{OAc}$ (aq.), flow: $0.75 \mathrm{~mL} / \mathrm{min}$, UV detection at $370 \mathrm{~nm}$ ).

Semi-preparative HPLC separation was performed by using the HPLC system implemented in the TRACERlab FX2 N synthesizer (GE Healthcare). A Reprosil-Pur $120 \mathrm{CN}$ column $(250 \times 20 \mathrm{~mm}, 10$

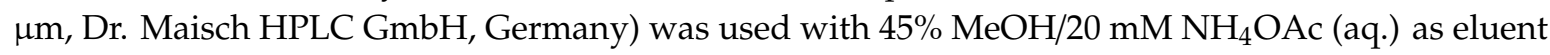
mixture and a flow rate of $7.0 \mathrm{~mL} / \mathrm{min}$. The ammonium acetate concentration stated as aq. $20 \mathrm{mM}$ $\mathrm{NH}_{4} \mathrm{OAc}$, corresponds to the concentration in the aqueous component of an eluent mixture.

The molar activities were determined based on a calibration curve carried out under isocratic HPLC conditions (Reprosil-Pur C18-AQ, $250 \times 4.6 \mathrm{~mm}, 30 \% \mathrm{MeOH} / 20 \mathrm{mM} \mathrm{NH} \mathrm{OAc}_{4}$ (aq.), flow: $0.75 \mathrm{~mL} / \mathrm{min}$ ) using chromatograms obtained at $370 \mathrm{~nm}$ as an appropriate maximum of UV absorbance.

\subsubsection{Radiosynthesis of $\left[{ }^{18} \mathrm{~F}\right] \mathbf{1}$}

No carrier added $\left[{ }^{18} \mathrm{~F}\right]$ fluoride in $1.5 \mathrm{~mL}$ water was trapped on a Sep-Pak Accell Plus QMA Carbonate Plus light cartridge (Waters $\mathrm{GmbH}$, Eschborn, Germany). The activity was eluted with $400 \mu \mathrm{L}$ of an aqueous solution of potassium carbonate $\left(\mathrm{K}_{2} \mathrm{CO}_{3}, 1.8 \mathrm{mg}, 13 \mu \mathrm{mol}\right)$ into a $4 \mathrm{~mL}$-shape vial prefilled with Kryptofix ${ }^{\circledR} 2.2 .2\left(\mathrm{~K}_{2.2 .2}, 11 \mathrm{mg}, 29 \mu \mathrm{mol}\right)$ in $1 \mathrm{~mL}$ ACN. The aqueous [ $\left.{ }^{18} \mathrm{~F}\right]$ fluoride was azeotropically dried under vacuum and nitrogen flow within 7-10 min using a single mode microwave (75 W, at 50-60 ${ }^{\circ} \mathrm{C}$, power cycling mode; Discover PETWave from CEM GmbH, Kamp-Lintfort, Germany) [60]. Two aliquots of $\mathrm{ACN}(2 \times 1.0 \mathrm{~mL})$ were added during the drying procedure and the final complex was obtained in a dried form. A solution of $1.0 \mathrm{mg}$ of the nitro precursor $15 \mathrm{in} 750 \mu \mathrm{L}$ 
DMSO was added, and the ${ }^{18} \mathrm{~F}$-labeling was performed at $130{ }^{\circ} \mathrm{C}$. To determine the radiochemical yields of the labeling process, samples were taken at different time points $(5,10,15$, and $20 \mathrm{~min})$ and analyzed by radio-HPLC and radio-TLC.

After cooling to $<30{ }^{\circ} \mathrm{C}$, the reaction mixture was diluted with $2.0 \mathrm{~mL}$ aqueous $\mathrm{NH}_{4} \mathrm{HCO}_{2}$ (adjusted to $\mathrm{pH} 4$ with formic acid) and $2.0 \mathrm{~mL} \mathrm{MeOH} /$ water (1:/1) and directly applied to an isocratic semi-preparative RP-HPLC for isolation of $\left[{ }^{18} \mathrm{~F}\right] \mathbf{1}$. The collected radiotracer fraction was diluted with $40 \mathrm{~mL}$ water to perform final purification by sorption on a Sep-Pak ${ }^{\circledR}$ C18 light cartridge (Waters, $\mathrm{GmbH}$, Eschborn, Germany) and successive elution with $1.3 \mathrm{~mL}$ of ethanol. The ethanolic solution was concentrated under a gentle argon stream at $70{ }^{\circ} \mathrm{C}$ to a final volume of $10-50 \mu \mathrm{L}$. Afterwards, the radiotracer was diluted in isotonic saline to obtain a final product containing $10 \%$ of EtOH $(v / v)$.

\subsubsection{Determination of In Vitro Stability and $\log \mathrm{D}_{7.4}$ of $\left[{ }^{18} \mathrm{~F}\right] \mathbf{1}$}

In vitro stability was investigated by incubation of about $5 \mathrm{MBq}$ of $\left[{ }^{18} \mathrm{~F}\right] \mathbf{1}$ in phosphate-buffered saline (PBS, pH 7.4), $n$-octanol, saline and ethanol $(500 \mu \mathrm{L})$ at $40{ }^{\circ} \mathrm{C}$ up to $60 \mathrm{~min}$. Samples were taken at $60 \mathrm{~min}$ and the radio-TLC and radio-HPLC analyses were performed.

The lipophilicity of $\left[{ }^{18} \mathrm{~F}\right] \mathbf{1}$ was experimentally determined by partitioning a small amount of the radiotracer between $n$-octanol and PBS ( $\mathrm{pH} 7.4)$ at room temperature using the conventional shake-flask method. The radiotracer $(15 \mu \mathrm{L}, \sim 800 \mathrm{kBq})$ was added to the tubes containing a mixture of $n$-octanol and PBS (3.0 mL, $\mathrm{n}=4)$. After shaking for $20 \mathrm{~min}$ using the mechanical shaker (HS250 basic, IKA Labortechnik GmbH \& Co. KG, Staufen, Germany), the samples were centrifuged for $5 \mathrm{~min}$ at $5000 \mathrm{rpm}$, followed by separation of the phases. Aliquots were taken from the organic and the aqueous phases $(1 \mathrm{~mL}$ of each) and activity was measured in a $\gamma$-counter (PerkinElmer Wallac Wizard 1480 Gamma Counter, manufactured by WALLAC, Turku, Finland). For the second extraction, another $1 \mathrm{~mL}$ aliquot of the organic layer was mixed with $2.0 \mathrm{~mL} n$-octanol and $3.0 \mathrm{~mL}$ of PBS and was subjected to the same procedure. The distribution coefficient (D) was calculated as [activity $(\mathrm{cpm} / \mathrm{mL})$ in $n$-octanol]/[activity (cpm/mL) in PBS, $\mathrm{pH} 7.4]$ stated as the decade logarithm $\left(\log \mathrm{D}_{7.4}\right)$.

\subsection{Animal Studies}

\subsubsection{General Information}

All experimental work including animals has been conducted in accordance with the national legislation on the use of animals for research (Tierschutzgesetz (TierSchG), TierschutzVersuchstierverordnung (TierSchVersV)) and has been approved by the responsible research ethics committee (TVV 18/18, DD24.1-5131/446/19, Landesdirektion Sachsen, 20 June, 2018). Female CD-1 mice, 10-12 weeks, were obtained from the Medizinisch-ExperimentellesZentrum at Universität Leipzig. For the time of the experiments, the animals were kept in a dedicated climatic chamber with free access to water and food under a 12:12 h dark:light cycle at a constant temperature of $24{ }^{\circ} \mathrm{C}$.

\subsubsection{In Vitro Autoradiographic Analysis of Binding Sites of $\left[{ }^{18} \mathrm{~F}\right] \mathbf{1}$ in Mouse Kidney}

The kidneys was isolated after cervical dislocation from one CD-1 mouse, frozen rapidly in isopentane at $-25{ }^{\circ} \mathrm{C}$ for $5 \mathrm{~min}$, and stored at $-25^{\circ} \mathrm{C}$ until the sectioning. Cryosections (transversal, $10 \mu \mathrm{m}$ ) were obtained using a microtome (MICROM HM560, Thermo Scientific Microm, Fisher Scientific $\mathrm{GmbH}$, Schwerte, Germany), mounted on microscopy slides (SuperFrost, Thermo Scientific Menzel, Fisher Scientific $\mathrm{GmbH}$, Schwerte, Germany), dried for $\sim 2 \mathrm{~h}$ at room temperature, and stored at $-25^{\circ} \mathrm{C}$ until the autoradiography study. For the experiment, the slides were taken out from the freezer, the cryosections dried under a stream of cold air, and pre-incubated with PBS for 15 min at room temperature. The incubation solution was decanted, the slices dried again under a stream of cold air, and covered afterwards with the incubation solution $\left(\left[{ }^{18} \mathrm{~F}\right] 1,198 \mathrm{kBq} / \mathrm{mL}\right.$ PBS or $1.19 \mathrm{nM}$ at the time of incubation, without (total binding) or with co-incubation with $10^{-5}, 10^{-7}$, and $10^{-9} \mathrm{M} \alpha-\mathrm{CHC}-\mathrm{Na}$ ). Incubation at room temperature was terminated after $60 \mathrm{~min}$, the slides were washed twice in $50 \mathrm{mM}$ 
TRIS-HCl, pH 7.4 at $4{ }^{\circ} \mathrm{C}$, on ice for two minutes each followed by dipping in ice-cold demineralized water for $5 \mathrm{~s}$ and rapid drying under a stream of cold air. Afterwards, the slides were exposed to a phosphor imager plate (BAS-IP TR 2025, FujiFilm Corporation, Tokyo, Japan) along with standards obtained by pipetting and drying $1 \mu \mathrm{L}$ of each concentration of a serial dilution of the radiotracer solution on to a microscopic slide.

\subsubsection{Analysis of Radiometabolites of $\left[{ }^{18} \mathrm{~F}\right] \mathbf{1}$ in Mouse}

The radiotracer $\left[{ }^{18} \mathrm{~F}\right] \mathbf{1}$ (32.84 MBq in $200 \mu \mathrm{L}$ isotonic saline) was injected in an awake female CD-1 mouse (12 weeks old, $31 \mathrm{~g}$ ) via the tail vein. After $30 \mathrm{~min}$, the animal was slightly anesthetized with isoflurane, and blood was collected from retro-orbital bleeding followed by cervical dislocation. Blood plasma was separated by centrifugation of the blood sample at 10,000 rpm for $2 \mathrm{~min}$. Brain was also isolated, cleaned by pouring PBS and homogenized in demineralized water $(\sim 2 \mathrm{~mL} / \mathrm{g}$ tissue $)$ in a borosilicate glass with a PTFE plunger by 10 strokes at 1000 rpm (POTTER S, Homogenizer, B. Braun Biotech, Sartorius AG, Göttingen, Germany). Blood plasma and brain homogenate were provided for preparation of samples for radio-HPLC analyses as described in the following.

RP-HPLC: Protein precipitation was performed by addition of an ice-cold $\mathrm{ACN} / \mathrm{H}_{2} \mathrm{O}$ mixture (9:1) to the plasma and brain samples in a ratio of 4:1 $(v / v$ : solvent/tissue sample, $n=2)$. The samples were vortexed for $2 \mathrm{~min}$, incubated on ice for $3 \mathrm{~min}$, and the suspensions were centrifuged at 10,000 rpm at $4{ }^{\circ} \mathrm{C}$ for $5 \mathrm{~min}$. For the second extraction, the precipitates were re-dissolved in $100 \mu \mathrm{L}$ of the solvent mixture, vortexed for $3 \mathrm{~min}$, incubated on ice for $5 \mathrm{~min}$ and subjected to the same centrifuging procedure. The combined supernatants (total volume between $1-2 \mathrm{~mL}$ ) were concentrated at $70^{\circ} \mathrm{C}$ under argon flow to a final volume of approximately $100 \mu \mathrm{L}$ and were analyzed by analytical radio-HPLC. A Reprosil-Pur C18-AQ column $(250 \mathrm{~mm} \times 4.6 \mathrm{~mm} ; 5 \mu \mathrm{m})$ was used as stationary phase and elution was done using the gradient mode as described in Section 3.3.1. To determine the percentage of radioactivity in the supernatants compared to total activity, aliquots of each step as well as the precipitates were quantified by gamma counting.

MLC: Preparation of the plasma and brain samples was performed as already described $[47,48]$. A Reprosil-Pur C18-AQ column $(250 \times 4.6 \mathrm{~mm}$, particle size: $10 \mu \mathrm{m})$ coupled with a pre-column of 10 $\mathrm{mm}$ length was used. Separations were performed by using an isocratic mode with an aqueous eluent containing $50 \mathrm{mM}$ sodium dodecyl sulfate and $10 \mathrm{mM} \mathrm{Na}_{2} \mathrm{HPO}_{4}$ at a flow rate of $1.0 \mathrm{~mL} / \mathrm{min}$.

\subsubsection{Small Animal Micro-PET/MR Studies}

The dynamic biodistribution of the radiotracers was assessed by small animal PET (nanoscan, Mediso, Hungary) over 60 min PET with a subsequently T1 weighted MR. Anaesthetized (2\% isofluran, carrier gas mixture of $40 \%$ air and $60 \% \mathrm{O}_{2}$ ) female CD-1 mice (bodyweight $=30.3 \pm 1.1 \mathrm{~g}$ ) were kept during imaging on a heated animal bed to sustain body temperature and were pretreated with vehicle $(0.9 \%$ saline $)$ and $\alpha-C H C-N a(25 \mathrm{mg} / \mathrm{kg}$ bodyweight $)$ prior to tracer application $\left(\left[{ }^{18} \mathrm{~F}\right] 1: 5.8 \pm 0.2 \mathrm{MBq}\right.$, $1.1 \mathrm{fmol} / \mathrm{g}$ bodyweight and $\left.{ }^{18} \mathrm{~F}\right] \mathrm{FACH}: 5.9 \pm 0.5 \mathrm{MBq}, 3.7 \pm 1.8 \mathrm{fmol} / \mathrm{g}$ ), whereby all injections were administered intravenously. The acquisitions were performed in normal mode and a coincidence Mode $1-5$. For subsequent dynamic reconstructions, list mode data were sorted into sinograms $(12 \times 10 \mathrm{~s}$, $6 \times 30 \mathrm{~s}, 5 \times 60 \mathrm{~s}$, and $10 \times 300 \mathrm{~s}$ ). The frames were reconstructed by Ordered Subset Expectation Maximization applied to 3D sinograms (OSEM3D) with an attenuation correction with 4 iterations, 6 subsets and a voxel size of $0.4 \mathrm{~mm}^{3}$ (Nucline v2.01, Mediso, Hungary). Analyses of reconstructed studies were performed with PMOD software (v4.005, PMOD Technologies LLC, Zurich, Switzerland) and results are expressed in Standardized Uptake Value (SUV).

\section{Conclusions}

In summary, two new analogs of FACH, 1 and 2, were synthesized and the former, with moderate MCT1 inhibition, was regarded to be a good PET candidate and therefore chosen for labeling with fluorine-18. Although the partition coefficient $\log \mathrm{D}_{7.4}$ of $\left[{ }^{18} \mathrm{~F}\right] \mathbf{1}$ was 2 -fold higher than the one 
of $\left[{ }^{18} \mathrm{~F}\right] \mathrm{FACH}$, the brain accumulation of both radiotracers was in a similar moderate range. This demonstrates that $\log \mathrm{D}_{7.4}$ alone does not govern passive diffusion into the brain, which is also reflected by comparing $\log \mathrm{D}_{7.4}$ with calculated $\log K_{\mathrm{BB}}$ (brain-blood partition coefficient). Nevertheless, the high uptake of $\left[{ }^{18} \mathrm{~F}\right] \mathbf{1}$ in kidney and other peripheral MCT-expressing organs together with the strong inhibition by specific drugs provide evidence that this radiotracer is suitable for future investigation of MCT imaging with PET. Moreover, these results suggest that further structural modifications towards improving MCT-mediated transport might result in higher brain uptake in vivo.

\section{Patents}

The nitro- or bromo- precursor for the radiosynthesis of the structurally modified analogs of FACH is subject of a patent application by Helmholtz-Zentrum Dresden-Rossendorf (DMPA registration No. 102019112 040.3) with following contributing inventors: Rareş-Petru Moldovan, Masoud Sadeghzadeh, Barbara Wenzel, Mathias Kranz, Steffen Fischer, Rodrigo Teodoro, Friedrich-Alexander Ludwig, Magali Toussaint and Peter Brust.

Supplementary Materials: The following are available online. Figure S1: (A) Representative semi-preparative radioand UV-HPLC chromatograms representing two peaks a/b which are supposed to reflect neutral and deprotonated form of the radiotracer $\left(\left[{ }^{18} \mathrm{~F}\right] \mathbf{1 a} / \mathbf{b}\right)$ (conditions: Reprosil-Pur $120 \mathrm{CN}, 10 \mu \mathrm{m}, 250 \times 20 \mathrm{~mm}, 45 \% \mathrm{MeOH} / 20 \mathrm{mM}$ $\mathrm{NH}_{4} \mathrm{OAc}$ (aq.), $7.0 \mathrm{~mL} / \mathrm{min}$ ); (B) Analytical radio- and UV-HPLC chromatograms detected two peaks a/b which assumed to be the neutral and deprotonated form of the final product $\left(\left[{ }^{18} \mathrm{~F}\right] \mathbf{1} \mathbf{a} / \mathbf{b}\right)$ in the sample solution co-eluted with the non-radioactive reference 1 (conditions: Reprosil-Pur C18-AQ, $250 \times 4.6 \mathrm{~mm}$, gradient with an eluent mixture of $\mathrm{ACN} / 20 \mathrm{mM} \mathrm{NH}_{4} \mathrm{OAc}$ (aq.), $1.0 \mathrm{~mL} / \mathrm{min}$ )., Figure S2: Analytical UV- and radio-HPLC chromatograms representing two peaks $\mathrm{a} / \mathrm{b}$ which are supposed to reflect the neutral and deprotonated form of the radiotracer $\left(\left[{ }^{18} \mathrm{~F}\right] \mathbf{1 a} / \mathbf{b}\right)$ in the mouse brain sample at 30 min p.i. measured under reversed-phase conditions (Reprosil-Pur C18-AQ, $250 \times 4.6 \mathrm{~mm}$, gradient with an eluent mixture of $\mathrm{ACN} / 20 \mathrm{mM} \mathrm{NH}_{4} \mathrm{OAc}$ (aq.), $370 \mathrm{~nm}, 1.0 \mathrm{~mL} / \mathrm{min}$ ).

Author Contributions: Conceptualization, M.S., B.W., W.D.-C., R.-P.M., L.R.D. and P.B.; Data curation, D.G., M.T., F.-A.L., and G.S.; Formal analysis, D.G., W.D.-C., F.L., S.J., and S.K.J.; Funding acquisition, M.S., L.R.D., and P.B.; Investigation, M.S., B.W., D.G., W.D.-C., M.T., S.J., S.K.J., G.S., and V.R.M.; Methodology, M.S., B.W., S.F., R.T., G.S., and V.R.M.; Project administration, M.S. and P.B.; Resources, W.D.-C., R.T., S.F., and V.R.M.; Software, D.G. and G.S.; Supervision, L.R.D. and P.B.; Validation, B.W., D.G., W.D.-C, R.-P.M., F.-A.L., R.T., S.K.J., V.R.M., L.R.D., and P.B.; Visualization, M.S.; Writing—original draft, M.S., B.W., G.S., and D.G.; Writing-review \& editing, M.S., B.W., D.G., W.D.-C., M.T., R.-P.M., S.F., F.-A.L., R.T., S.J., S.K.J., G.S., V.R.M., L.R.D., and P.B. All authors have read and agreed to the published version of the manuscript.

Funding: Masoud Sadeghzadeh was kindly financially supported by the Alexander von Humboldt Foundation and L. R. Drewes was supported by the University of Minnesota Foundation. This research received no further external funding.

Acknowledgments: The Alexander von Humboldt Foundation and the University of Minnesota Duluth are acknowledged for financial supports. We are thankful to K. Franke and A. Mansel for providing $\left[{ }^{18} \mathrm{~F}\right] \mathrm{fluoride}$ as well as Matthias Scheunemann and Susann Schröder for their scientific supports. We also thank the staff of the Institute of Analytical Chemistry, Department of Chemistry and Mineralogy of the University of Leipzig, for recording and processing the NMR and HR-MS spectra.

Conflicts of Interest: The authors declare no conflict of interest. The Humboldt Foundation had no role in the design of the study; in the collection, analyses, or interpretation of data; in the writing of the manuscript, or in the decision to publish the results.

\section{References}

1. Halestrap, A.P.; Meredith, D. The SLC16 gene family-From monocarboxylate transporters (MCTs) to aromatic amino acid transporters and beyond. Pflüger, Archiv für die Gesammte Physiologie des Menschen und der Thiere 2004, 447, 619-628. [CrossRef] [PubMed]

2. Jones, R.S.; Morris, A.M.E. Monocarboxylate Transporters: Therapeutic Targets and Prognostic Factors in Disease. Clin. Pharmacol. Ther. 2016, 100, 454-463. [CrossRef] [PubMed]

3. Halestrap, A.P.; Wilson, M.C. The monocarboxylate transporter family-Role and regulation. IUBMB Life 2011, 64, 109-119. [CrossRef] 
4. Hong, C.S.; Graham, N.A.; Gu, W.; Camacho, C.E.; Mah, V.; Maresh, E.L.; Alavi, M.; Bagryanova, L.; Krotee, P.A.L.; Gardner, B.K.; et al. MCT1 Modulates Cancer Cell Pyruvate Export and Growth of Tumors that Co-express MCT1 and MCT4. Cell Rep. 2016, 14, 1590-1601. [CrossRef] [PubMed]

5. Park, S.J.; Smith, C.P.; Wilbur, R.R.; Cain, C.P.; Kallu, S.R.; Valasapalli, S.; Sahoo, A.; Guda, M.R.; Tsung, A.J.; Velpula, K.K. An overview of MCT1 and MCT4 in GMB: Small molecule transporters with large implications. Am. J. Cancer Res. 2018, 8, 1967-1976. [PubMed]

6. Cao, Y.-W.; Liu, Y.; Dong, Z.; Guo, L.; Kang, E.-H.; Wang, Y.-H.; Zhang, W.; Niu, H.-T. Monocarboxylate transporters MCT1 and MCT4 are independent prognostic biomarkers for the survival of patients with clear cell renal cell carcinoma and those receiving therapy targeting angiogenesis. Urol. Oncol. Semin. Orig. Investig. 2018, 36, 311.e15-311.e25. [CrossRef]

7. Marchiq, I.; Pouysségur, J. Hypoxia, cancer metabolism and the therapeutic benefit of targeting lactate/H(+) symporters. J. Mol. Med. 2015, 94, 155-171. [CrossRef]

8. Roy, D.; Sheng, G.Y.; Herve, S.; Carvalho, E.; Mahanty, A.; Yuan, S.; Sun, L. Interplay between cancer cell cycle and metabolism: Challenges, targets and therapeutic opportunities. Biomed. Pharm. 2017, 89, 288-296. [CrossRef]

9. Zhu, A.; Lee, D.; Shim, H. Metabolic positron emission tomography imaging in cancer detection and therapy response. Semin. Oncol. 2011, 38, 55-69. [CrossRef]

10. O'Neill, H.; Malik, V.; Johnston, C.; Reynolds, J.V.; O'Sullivan, J. Can the Efficacy of [ ${ }^{18}$ F]FDG-PET/CT in Clinical Oncology Be Enhanced by Screening Biomolecular Profiles? Pharmaceuticals 2019, 12, 16. [CrossRef]

11. Endo, K.; Oriuchi, N.; Higuchi, T.; Iida, Y.; Hanaoka, H.; Miyakubo, M.; Ishikita, T.; Koyama, K. PET and PET/CT using ${ }^{18}$ F-FDG in the diagnosis and management of cancer patients. Int. J. Clin. Oncol. 2006, 11, 286-296. [CrossRef] [PubMed]

12. Ganapathy-Kanniappan, S.; Geschwind, J.-F. Tumor glycolysis as a target for cancer therapy: Progress and prospects. Mol. Cancer 2013, 12, 152. [CrossRef] [PubMed]

13. Draoui, N.; Feron, O. Lactate shuttles at a glance: From physiological paradigms to anti-cancer treatments. Dis. Model. Mech. 2011, 4, 727-732. [CrossRef] [PubMed]

14. Ocaña, M.C.; Poveda, B.M.; Quesada, A.R.; Medina, M. Ángel Metabolism within the tumor microenvironment and its implication on cancer progression: An ongoing therapeutic target. Med. Res. Rev. 2018, 39, 70-113. [CrossRef] [PubMed]

15. Beinat, C.; Patel, C.; Haywood, T.; Murty, S.; Alam, I.; Xie, Y.; Gandhi, H.; Holley, D.; Gambhir, S. Evaluation of $\left[{ }^{18}\right.$ F]DASA-23 for non-invasive measurement of aberrantly expressed pyruvate kinase $\mathrm{M} 2$ in glioblastoma: Preclinical and first in human studies. J. Nucl. Med. 2019, 60, 52.

16. Fu, Y.; Liu, S.; Yin, S.; Niu, W.; Xiong, W.; Tan, M.; Li, G.; Zhou, M. The reverse Warburg effect is likely to be an Achilles' heel of cancer that can be exploited for cancer therapy. Oncotarget 2017, 8, 57813-57825. [CrossRef]

17. Herrero, P.; Dence, C.S.; Coggan, A.R.; Kisrieva-Ware, Z.; Eisenbeis, P.; Gropler, R.J. L-3- ${ }^{11}$ C-Lactate as a PET Tracer of Myocardial Lactate Metabolism: A Feasibility Study. J. Nucl. Med. 2007, 48, 2046-2055. [CrossRef]

18. Yokoi, F.; Hara, T.; Iio, M.; Nonaka, I.; Satoyoshi, E. 1-[ $\left[{ }^{11} \mathrm{C}\right]$ pyruvate turnover in brain and muscle of patients with mitochondrial encephalomyopathy. A study with positron emission tomography (PET). J. Neurol. Sci. 1990, 99, 339-348. [CrossRef]

19. Graham, K.; Müller, A.; Lehmann, L.; Koglin, N.; Dinkelborg, L.; Siebeneicher, H. $\left[{ }^{18}\right.$ F]Fluoropyruvate: Radiosynthesis and initial biological evaluation. J. Label. Compd. Radiopharm. 2014, 57, 164-171. [CrossRef]

20. Van Hée, V.F.; Labar, D.; Dehon, G.; Grasso, D.; Grégoire, V.; Muccioli, G.G.; Frédérick, R.; Sonveaux, P. Radiosynthesis and validation of $( \pm)-\left[{ }^{18} \mathrm{~F}\right]-3$-fluoro-2-hydroxypropionate ([18F]-FLac) as a PET tracer of lactate to monitor MCT1-dependent lactate uptake in tumors. Oncotarget 2017, 8, 24415. [CrossRef]

21. Tateishi, H.; Tsuji, A.B.; Kato, K.; Sudo, H.; Sugyo, A.; Hanakawa, T.; Zhang, M.-R.; Saga, T.; Arano, Y.; Higashi, T. Synthesis and evaluation of ${ }^{11} \mathrm{C}$-labeled coumarin analog as an imaging probe for detecting monocarboxylate transporters expression. Bioorganic Med. Chem. Lett. 2017, 27, 4893-4897. [CrossRef] [PubMed]

22. Wang, X.; Levi, A.J.; Halestrap, A.P. Substrate and inhibitor specificities of the monocarboxylate transporters of single rat heart cells. Am. J. Physiol. Circ. Physiol. 1996, 270, H476-H484. [CrossRef] [PubMed]

23. Hildyard, J.C.W.; Halestrap, A.P. Identification of the mitochondrial pyruvate carrier in Saccharomyces cerevisiae. Biochem. J. 2003, 374, 607-611. [CrossRef] [PubMed] 
24. Gurrapu, S.; Jonnalagadda, S.; Alam, M.A.; Nelson, G.L.; Sneve, M.G.; Drewes, L.R.; Mereddy, V.R. Monocarboxylate Transporter 1 Inhibitors as Potential Anticancer Agents. ACS Med. Chem. Lett. 2015, 6, 558-561. [CrossRef] [PubMed]

25. Jonnalagadda, S.; Jonnalagadda, S.K.; Ronayne, C.T.; Nelson, G.L.; Solano, L.N.; Rumbley, J.; Holy, J.; Mereddy, V.R.; Drewes, L.R. Novel N,N-dialkyl cyanocinnamic acids as monocarboxylate transporter 1 and 4 inhibitors. Oncotarget 2019, 10, 2355-2368. [CrossRef] [PubMed]

26. Sadeghzadeh, M.; Moldovan, R.-P.; Fischer, S.; Wenzel, B.; Ludwig, F.-A.; Teodoro, R.; Deuther-Conrad, W.; Jonnalagadda, S.; Jonnalagadda, S.K.; Gudelis, E.; et al. Development and radiosynthesis of the first ${ }^{18}$ F-labeled inhibitor of monocarboxylate transporters (MCTs). J. Label. Compd. Radiopharm. 2019, 62, 411-424. [CrossRef]

27. Sadeghzadeh, M.; Moldovan, R.; Wenzel, B.; Kranz, M.; Deuther-Conrad, W.; Toussaint, M.; Fischer, S.; Ludwig, F.-A.; Teodoro, R.; Jonnalagadda, S.; et al. Development of the first F-18-labeled MCT1/MCT4 lactate transport inhibitor: Radiosynthesis and preliminary in vivo evaluation in mice. In Proceedings of the 23rd International Symposium on Radiopharmaceutical Sciences, Beijing, China, 26-31 May 2019; Volume 62, pp. S59-S60.

28. Sadeghzadeh, M.; Moldovan, R.-P.; Teodoro, R.; Brust, P.; Wenzel, B. One-step radiosynthesis of the MCTs imaging agent $\left[{ }^{18} \mathrm{~F}\right] \mathrm{FACH}$ by aliphatic $18 \mathrm{~F}$-labelling of a methylsulfonate precursor containing an unprotected carboxylic acid group. Sci. Rep. 2019, 9, 1-8. [CrossRef]

29. Colen, C.B.; Seraji-Bozorgzad, N.; Marples, B.; Galloway, M.; Sloan, A.E.; Mathupala, S.P. Metabolic Remodeling Of Malignant Gliomas For Enhanced Sensitization During Radiotherapy. Neurosurgery 2006, 59, 1313-1324. [CrossRef]

30. Mathupala, S.P.; Colen, C.B.; Parajuli, P.; Sloan, A.E. Lactate and malignant tumors: A therapeutic target at the end stage of glycolysis. J. Bioenerg. Biomembr. 2007, 39, 73-77. [CrossRef]

31. Omori, K.; Tachikawa, M.; Hirose, S.; Taii, A.; Akanuma, S.-I.; Hosoya, K.-I.; Terasaki, T. Developmental changes in transporter and receptor protein expression levels at the rat blood-brain barrier based on quantitative targeted absolute proteomics. Drug Metab. Pharmacokinet. 2020, 35, 117-123. [CrossRef]

32. Colen, C.B.; Shen, Y.; Ghoddoussi, F.; Yu, P.; Francis, T.B.; Koch, B.J.; Monterey, M.D.; Galloway, M.; Sloan, A.E.; Mathupala, S.P. Metabolic Targeting of Lactate Efflux by Malignant Glioma Inhibits Invasiveness and Induces Necrosis: An In Vivo Study. Neoplasia 2011, 13, 620-632. [CrossRef] [PubMed]

33. Miranda-Gonçalves, V.; Honavar, I.; Pinheiro, C.; Martinho, O.; Pires, M.; Pinheiro, C.; Cordeiro, M.; Bebiano, G.; Costa, P.; Palmeirim, I.; et al. Monocarboxylate transporters (MCTs) in gliomas: Expression and exploitation as therapeutic targets. Neuro Oncol. 2012, 15, 172-188. [CrossRef] [PubMed]

34. Serafimova, I.M.; Pufall, M.A.; Krishnan, S.; Duda, K.; Cohen, M.S.; Maglathlin, R.L.; McFarland, J.M.; Miller, R.M.; Frödin, M.; Taunton, J. Reversible targeting of noncatalytic cysteines with chemically tuned electrophiles. Nat. Methods 2012, 8, 471-476. [CrossRef] [PubMed]

35. Halestrap, A.P. The mechanism of the inhibition of the mitochondrial pyruvate transportater by $\alpha$-cyanocinnamate derivatives. Biochem. J. 1976, 156, 181-183. [CrossRef] [PubMed]

36. Koley, M.; Wimmer, L.; Schnürch, M.; Mihovilovic, M.D. Regioselective Syntheses of 2,3-Substituted Pyridines by Orthogonal Cross-Coupling Strategies. Eur. J. Org. Chem. 2011, 2011, 1972-1979. [CrossRef]

37. Begouin, A.; Hesse, S.; Queiroz, M.J.R.P.; Kirsch, G. Palladium-Catalyzed Buchwald-Hartwig Coupling of Deactivated Aminothiophenes with Substituted Halopyridines. Eur. J. Org. Chem. 2007, 2007, 1678-1682. [CrossRef]

38. Schumacher, R.A.; Hopper, A.T.; Tehim, A.; Hess, H.-E.; Unterbeck, A.; Kuester, E.; Brubaker, W.F.; Dunn, R.F. Phosphodiesterase 4 Inhibitors, including N-Substituted Aniline and Diphenylamine Analogs. U.S. Patents 7,405,230 B2, 29 July 2008.

39. Vilsmeier, A.; Haack, A. Über die einwirkung von halogenphosphor auf alkyl-formanilide. Eine neue methode zur darstellung sekundärer und tertiärer P-alkylamino-benzaldehyde. Eur. J. Inorg. Chem. 1927, 60, 4. [CrossRef]

40. Roux, F.; Couraud, P.-O. Rat brain endothelial cell lines for the study of blood-brain barrier permeability and transport functions. Cell. Mol. Neurobiol. 2005, 25, 41-57. [CrossRef]

41. Pike, V.W. PET radiotracers: Crossing the blood-brain barrier and surviving metabolism. Trends Pharmacol. Sci. 2009, 30, 431-440. [CrossRef]

42. US EPA. Estimation Programs Interface Suite ${ }^{\mathrm{TM}}$ for Microsoft ${ }^{\circledR}$ Windows; Version 4.1; EPA: Washington, DC, USA, 2012. 
43. ACD/Percepta, Version 2726; ACD/Labs 2015 Release (Build 272627 November 2014); ACD/Labs: Toronto, ON, Canada. Available online: www.acdlabs.com (accessed on 4 May 2020).

44. Schüürmann, G. Ecotoxic Modes of Action of Chemical Substances. In Ecotoxicology: Ecological Fundamentals, Chemical Exposure and Biological Effects; Schüürmann, G., Markert, B., Eds.; John Wiley; Spektrum Akademischer Verlag: New York, NY, USA, 1998; pp. 665-749.

45. Wang, Q.; Lu, Y.; Yuan, M.; Darling, I.M.; Repasky, E.A.; Morris, A.M.E. Characterization of Monocarboxylate Transport in Human Kidney HK-2 Cells. Mol. Pharm. 2006, 3, 675-685. [CrossRef]

46. Becker, H.M.; Mohebbi, N.; Perna, A.; Ganapathy, V.; Capasso, G.; Wagner, C.A. Localization of members of MCT monocarboxylate transporter family Slc16 in the kidney and regulation during metabolic acidosis. Am. J. Physiol. Physiol. 2010, 299, F141-F154. [CrossRef] [PubMed]

47. Lindemann, M.; Hinz, S.; Deuther-Conrad, W.; Namasivayam, V.; Dukic-Stefanovic, S.; Teodoro, R.; Toussaint, M.; Kranz, M.; Juhl, C.; Steinbach, J.; et al. Radiosynthesis and in vivo evaluation of a fluorine-18 labeled pyrazine based radioligand for PET imaging of the adenosine A 2B receptor. Bioorganic Med. Chem. 2018, 26, 4650-4663. [CrossRef] [PubMed]

48. Nakao, R.; Amini, N.; Halldin, C. Simultaneous Determination of Protein-Free and Total Positron Emission Tomography Radioligand Concentrations in Plasma Using High-Performance Frontal Analysis Followed by Mixed Micellar Liquid Chromatography: Application to [ ${ }^{11}$ C]PBR28 in Human Plasma. Anal. Chem. 2013, 85, 8728-8734. [CrossRef] [PubMed]

49. Pierre, K.; Pellerin, L. Monocarboxylate transporters in the central nervous system: Distribution, regulation and function. J. Neurochem. 2005, 94, 1-14. [CrossRef] [PubMed]

50. Vijay, N.; Morris, A.M.E. Role of monocarboxylate transporters in drug delivery to the brain. Curr. Pharm. Des. 2014, 20, 1487-1498. [CrossRef] [PubMed]

51. Spector, R. Micronutrient Homeostasis in Mammalian Brain and Cerebrospinal Fluid. J. Neurochem. 1989, 53, 1667-1674. [CrossRef]

52. Friedland, R.P.; Mathis, C.A.; Budinger, T.F.; Moyer, B.R.; Rosen, M. Labeled choline and phosphorylcholine: Body distribution and brain autoradiography: Concise communication. J. Nucl. Med. 1983, 24, 812-815.

53. Rosen, M.A.; Jones, R.M.; Yano, Y.; Budinger, T.F. Carbon-11 choline: Synthesis, purification, and brain uptake inhibition by 2-dimethylaminoethanol. J. Nucl. Med. 1985, 26, 1424-1428.

54. Hara, T.; Kosaka, N.; Shinoura, N.; Kondo, T. PET imaging of brain tumor with $\left[\right.$ methyl- ${ }^{11}$ C]choline. J. Nucl. Med. 1997, 38, 842-847.

55. Dardel, N.T.; Gómez-Río, M.; Triviño-Ibáñez, E.; Llamas-Elvira, J.M. Clinical applications of PET using C-11/F-18-choline in brain tumours: A systematic review. Clin. Transl. Imaging 2017, 5, 101-119. [CrossRef]

56. Evangelista, L.; Briganti, A.; Fanti, S.; Joniau, S.; Reske, S.; Schiavina, R.; Stief, C.; Thalmann, G.N.; Picchio, M. New Clinical Indications for ${ }^{18} \mathrm{~F} /{ }^{11} \mathrm{C}$-choline, New Tracers for Positron Emission Tomography and a Promising Hybrid Device for Prostate Cancer Staging: A Systematic Review of the Literature. Eur. Urol. 2016, 70, 161-175. [CrossRef] [PubMed]

57. Bergersen, L.H. Is lactate food for neurons? Comparison of monocarboxylate transporter subtypes in brain and muscle. Neuroscience 2007, 145, 11-19. [CrossRef]

58. Perez-Escuredo, J.; Van Hée, V.; Sboarina, M.; Falces, J.; Payen, V.L.; Pellerin, L.; Sonveaux, P. Monocarboxylate transporters in the brain and in cancer. Biochim. Biophys. Acta (BBA) Bioenerg. 2016, 1863, 2481-2497. [CrossRef] [PubMed]

59. Miranda-Gonçalves, V.; Bezerra, F.; Costa-Almeida, R.; Freitas-Cunha, M.; Soares, R.; Martinho, O.; Reis, R.M.; Pinheiro, C.; Baltazar, F. Monocarboxylate transporter 1 is a key player in glioma-endothelial cell crosstalk. Mol. Carcinog. 2017, 56, 2630-2642. [CrossRef]

60. Teodoro, R.; Wenzel, B.; Oh-Nishi, A.; Fischer, S.; Peters, D.; Suhara, T.; Deuther-Conrad, W.; Brust, P. A high-yield automated radiosynthesis of the alpha-7 nicotinic receptor radioligand $\left[{ }^{18} \mathrm{~F}\right] \mathrm{NS} 10743$. Appl. Radiat. Isot. 2015, 95, 76-84. [CrossRef] [PubMed]

Sample Availability: Samples of the compounds 1, 2 and 15 are available from the authors. 